Atmos. Chem. Phys., 14, 4201-4218, 2014

www.atmos-chem-phys.net/14/4201/2014/

doi:10.5194/acp-14-4201-2014

(c) Author(s) 2014. CC Attribution 3.0 License.

\title{
Dimers in $\alpha$-pinene secondary organic aerosol: effect of hydroxyl radical, ozone, relative humidity and aerosol acidity
}

\author{
K. Kristensen ${ }^{1}$, T. Cui ${ }^{2}$, H. Zhang ${ }^{2,}$, , A. Gold ${ }^{2}$, M. Glasius ${ }^{1}$, and J. D. Surratt ${ }^{2}$ \\ ${ }^{1}$ Department of Chemistry and iNANO, Aarhus University, DK-8000 Aarhus C., Denmark \\ ${ }^{2}$ Department of Environmental Sciences and Engineering, Gillings School of Global Public Health, University of North \\ Carolina at Chapel Hill, Chapel Hill, NC 27599, USA \\ *now at: Department of Environmental Science, Policy and Management, University of California, Berkeley, CA 94720, USA
}

Correspondence to: M. Glasius (marianne@glasius.dk) and J. Surratt (surratt@unc.edu)

Received: 14 November 2013 - Published in Atmos. Chem. Phys. Discuss.: 10 December 2013

Revised: 3 March 2014 - Accepted: 5 March 2014 - Published: 28 April 2014

\begin{abstract}
The formation of secondary organic aerosol (SOA) from both ozonolysis and hydroxyl radical $(\mathrm{OH})$-initiated oxidation of $\alpha$-pinene under conditions of high nitric oxide (NO) concentrations with varying relative humidity $(\mathrm{RH})$ and aerosol acidity was investigated in the University of North Carolina dual outdoor smog chamber facility. SOA formation from ozonolysis of $\alpha$-pinene was enhanced relative to that from $\mathrm{OH}$-initiated oxidation in the presence of initially highNO conditions. However, no effect of RH on SOA mass was evident. Ozone $\left(\mathrm{O}_{3}\right)$-initiated oxidation of $\alpha$-pinene in the presence of ammonium sulfate (AS) seed coated with organic aerosol from $\mathrm{OH}$-initiated oxidation of $\alpha$-pinene showed reduced nucleation compared to ozonolysis in the presence of pure AS seed aerosol.
\end{abstract}

The chemical composition of $\alpha$-pinene SOA was investigated by ultra-performance liquid chromatography/electrospray ionization high-resolution quadrupole timeof-flight mass spectrometry (UPLC/ESI-HR-Q-TOFMS), with a focus on the formation of carboxylic acids and highmolecular weight dimers. A total of eight carboxylic acids and four dimers were identified, constituting between 8 and $12 \%$ of the total $\alpha$-pinene SOA mass. OH-initiated oxidation of $\alpha$-pinene in the presence of nitrogen oxides $\left(\mathrm{NO}_{\mathrm{x}}\right)$ resulted in the formation of highly oxidized carboxylic acids, such as 3-methyl-1,2,3-butanetricarboxylic acid (MBTCA) and diaterpenylic acid acetate (DTAA). The formation of dimers was observed only in SOA produced from the ozonolysis of $\alpha$-pinene in the absence of $\mathrm{NO}_{\mathrm{x}}$, with increased concentrations by a factor of two at higher RH (50-90\%) relative to lower RH (30-50\%). The increased formation of dimers correlates with an observed increase in new particle formation at higher RH due to nucleation. Increased aerosol acidity was found to have a negligible effect on the formation of the dimers. SOA mass yield did not influence the chemical composition of SOA formed from $\alpha$-pinene ozonolysis with respect to carboxylic acids and dimers.

The results support the formation of the high-molecular weight dimers through gas-phase reactions of the stabilized Criegee Intermediate (sCI) formed from the ozonolysis of $\alpha$-pinene. The high molecular weight and polar nature of dimers formed in the gas phase may explain increased particle number concentration as a result of homogenous nucleation. Since three of these dimers (i.e. pinyl-diaterpenyl dimer (MW 358), pinyl-diaterebyl dimer (MW 344) and pinonyl-pinyl dimer (MW 368)) have been observed in both laboratory-generated and ambient fine organic aerosol samples, we conclude that the dimers observed in this study can be used as tracers for the $\mathrm{O}_{3}$-initiated oxidation of $\alpha$-pinene, and are therefore indicative of enhanced anthropogenic activities, and that the high molecular weight and low volatility dimers result in homogenous nucleation under laboratory conditions, increasing the particle number concentration.

\section{Introduction}

The formation of biogenic secondary organic aerosol (BSOA) through atmospheric processing of naturally emitted biogenic volatile organic compounds (BVOCs) comprises a major fraction of secondary organic aerosol (SOA) in the 


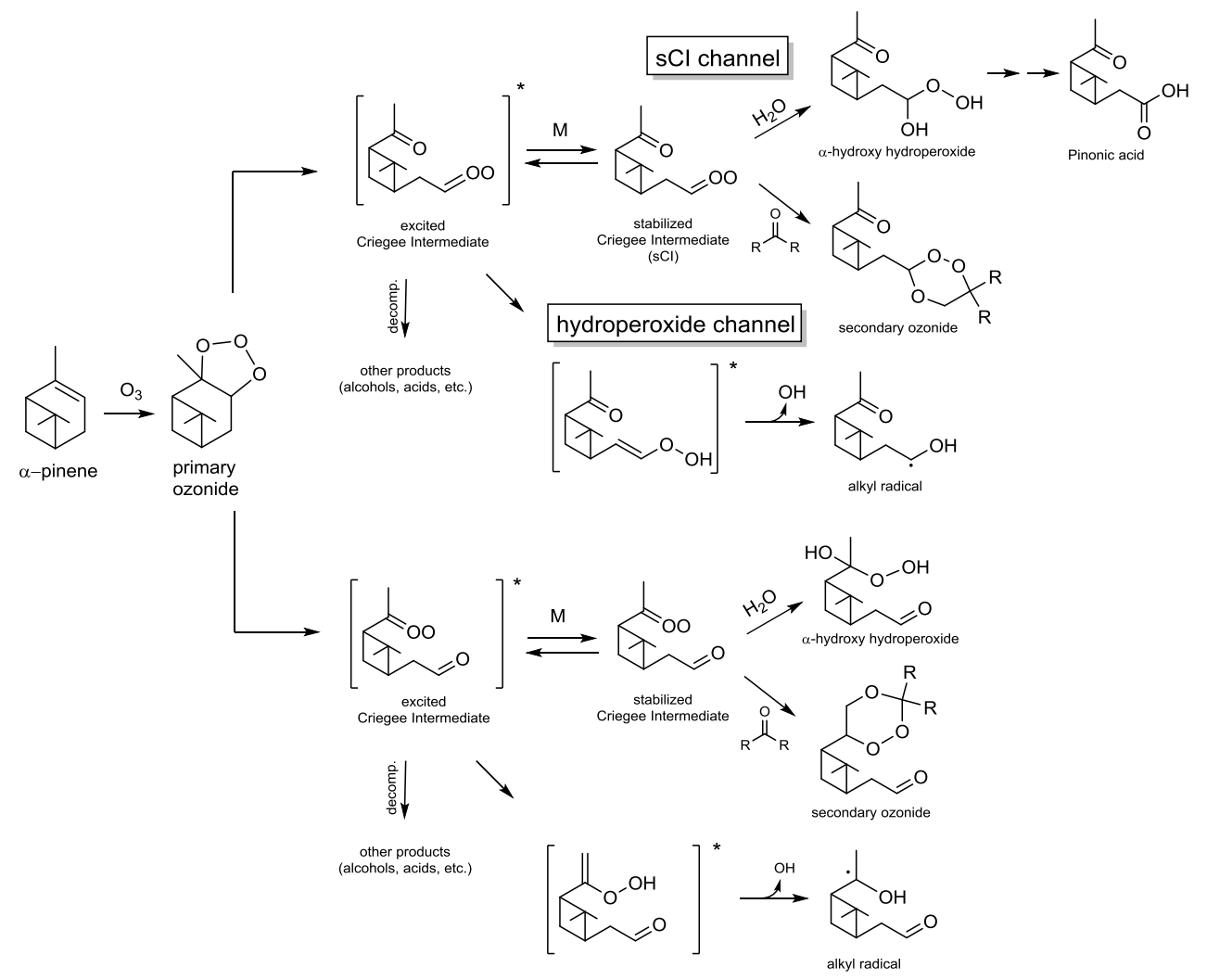

Fig. 1. Simplified mechanisms of the reaction of $\alpha$-pinene with $\mathrm{O}_{3}$ (adapted from Docherty et al., 2005, and Kroll and Seinfeld, 2008).

atmosphere (Hallquist et al., 2009). Monoterpenes $\left(\mathrm{C}_{10} \mathrm{H}_{16}\right)$, including $\alpha$-pinene, constitute an important group of BVOCs emitted from coniferous trees as well as other types of vegetation (Guenther et al., 1995). Once released, $\alpha$-pinene is quickly oxidized by hydroxyl radical $(\mathrm{OH})$ in the sunlit atmosphere, reaction with ozone $\left(\mathrm{O}_{3}\right)$, and during night-time, with nitrate radical $\left(\mathrm{NO}_{3}\right)$, resulting in a complex mixture of first-generation oxidation products consisting primarily of carbonyls, carboxylic acids, alcohols and organic nitrates (Warneke et al., 2004; Yu et al., 1999; Glasius et al., 2000; Larsen et al., 2001; Hallquist et al., 2009; Camredon et al., 2010; Perraud et al., 2010; Fry et al., 2009). Due to the lower vapour pressure of the oxidation products, they partition between the gas and particle phases, resulting in the formation of SOA (Kroll and Seinfeld, 2008; Odum et al., 1996; Hoffmann et al., 1997; Donahue et al., 2006; Jimenez et al., 2009).

$\mathrm{O}_{3}$ oxidation of $\alpha$-pinene proceeds via addition across the double bond, leading to the formation of an energy-rich primary ozonide (Fig. 1). The ozonide decomposes rapidly through one of two channels, each forming an energy-rich Criegee intermediate. The Criegee intermediates are either collisionally (stabilized Criegee Intermediate (sCI) channel, Fig. 1) or decompose to yield $\mathrm{OH}$ and an additional organic radical (hydroperoxide channel, Fig. 1). Although several reactions are possible for $\mathrm{sCI}$, reaction with water is be- lieved to predominate under atmospheric conditions (Atkinson and Arey, 1998; Kroll and Seinfeld, 2008), leading to the formation of an $\alpha$-hydroxy hydroperoxide and other firstgeneration oxidation products such as pinonaldehyde and pinonic acid (Jenkin et al., 2000; Kroll and Seinfeld, 2008). In addition, the sCI may also form a secondary ozonide through the reaction with carbonyl compounds (Fig. 1). Other important and more highly oxidized products, such as 10-hydroxy-pinonic and pinic acids, are formed from the decomposition of more highly substituted Criegee biradicals (Jenkin et al., 2000), while terpenylic acid has been shown to form through a pathway involving ozonolysis of $\alpha$-pinene and campholenic aldehyde. Here the reaction of ozone and $\alpha$-pinene leads to the formation $\alpha$-pinene oxide which can rearrange to campholenic aldehyde. Once formed, campholenic aldehyde may undergo further reaction with ozone to form terpenylic aldehyde, which can then be further oxidized in the particle phase to form terpenylic acid (Iinuma et al., 2013; Kahnt et al., 2014).

The first-generation oxidation products of $\alpha$-pinene may undergo further processing in the gas and aerosol phases, such as oxidation (Szmigielski et al., 2007; Müller et al., 2012), sulfation (Surratt et al., 2008; Iinuma et al., 2007) and oligomerization (Tolocka et al., 2004; Gao et al., 2004; Kalberer et al., 2004), resulting in the formation of less 
volatile, high-molecular weight compounds. For example, pinonic acid is semi-volatile and a significant fraction of pinonic acid is present in the gas phase at $283 \mathrm{~K}$ (Müller et al., 2012). Through further reaction with $\mathrm{OH}$, gas-phase pinonic acid is oxidized to the second-generation oxidation product 3-methyl-1,2,3-butane tricarboxylic acid (MBTCA) (Szmigielski et al., 2007; Zhang et al., 2010; Müller et al., 2012), which has low vapour pressure and rapidly partitions into the aerosol phase. Once condensed in the aerosol phase, other first-generation compounds, such as pinic and terpenylic acids, are believed to undergo oligomerization to form dimers (Yasmeen et al., 2010), which are effectively captured because of their low vapour pressure.

Species having compositions corresponding to structures tentatively identified as higher molecular weight esters originating from $\alpha$ - and $\beta$-pinene have been observed in both laboratory-generated and ambient SOA (Müller et al., 2008, 2009; Camredon et al., 2010; Yasmeen et al., 2010; Gao et al., 2010; Kristensen et al., 2013). Previously these compounds have been referred to as esters based on the assumed formation by liquid phase esterification or their structure, but in this work we use the term dimers. Yasmeen et al. (2010) presented the first field measurements of pinyl-diaterpenyl dimer (MW 358), diaterpenyl-terpenyl dimer (MW 344) and pinyl-diaterebyl dimer (MW 344) in ambient aerosols collected during warm nights at K-Puszta, Hungary. In addition, the pinyl-diaterpenyl dimer along with pinonyl-pinyl dimer (MW 368) have also recently been identified in both daytime and night-time aerosols collected from Blodgett Forest in the Sierra Nevada mountains, USA, at concentrations comparable to some first- and second-generation oxidation products from $\alpha$-pinene (Kristensen et al., 2013). The proposed chemical structures of the dimers have been derived by Yasmeen et al. (2010) from molecular weight and elemental formulas along with MS/MS data consistent with monomer acid building blocks. The formation of the pinyl-diaterpenyl dimer was explained by Yasmeen et al. (2010) as an esterification of cis-pinic acid with diaterpenylic acid, which was proposed to be generated as an intermediate by acid-catalysed hydrolysis of the $\alpha$-pinene oxidation products, terpenylic acid and/or diaterpenylic acid acetate (Yasmeen et al., 2010). The two MW 344 dimers have been hypothesized to originate from the esterification of terpenylic acid and diaterpenylic acid (diaterpenyl-terpenyl ester), and from diaterebic acid, a homologue of diaterpenylic acid, and cis-pinic acid (pinyldiaterebyl ester). The pinonyl-pinyl dimer is hypothesized to form from the esterification of cis-pinic and 10-hydroxypinonic acids (Yasmeen et al., 2010). Hence, these dimers have been tentatively proposed to be later-generation products formed through esterification in the aerosol phase. In contradiction to this hypothesis, the first observations of the MW 358 dimer by Hoffman et al. (1998) showed that the compounds were formed concomitantly with cis-pinic acid, cis-pinonic acid and a MW 172 monomer later assigned to terpenylic acid (Claeys et al., 2009). In line with this, Heaton et al. (2007) observed almost immediate formation of dimers and higher order oligomers in a flow tube study involving the ozonolysis of monoterpenes. Furthermore, a recent study has shown that dimers from $\alpha$-pinene ozonolysis are formed within the same time frame as their structural precursors (Kristensen et al., 2013). Using on-line atmospheric pressure chemical ionization mass spectrometry (APCI-MS) with high time resolution, Müller et al. (2008) observed that the intensity of dimers increased more rapidly than the intensity of their monomer precursors in freshly nucleated aerosol in the $\alpha$-pinene $/ \mathrm{O}_{3}$ system. This result led to the suggestion that gas-phase dimer formation could be important for homogeneous nucleation, although the exact reaction mechanism has remained elusive. Altogether, the formation mechanisms of dimers observed in fine aerosol recently collected from both K-Puszta, Hungary (Yasmeen et al., 2010), and in Blodgett Forest, USA (Kristensen et al., 2013), have yet to be elucidated.

In the present study, we address the formation of several first- and second-generation oxidation products along with four individual dimers formed from the oxidation of $\alpha$-pinene. We investigate the effect of oxidant species $(\mathrm{OH}$ vs. $\mathrm{O}_{3}$ ), relative humidity (RH) and seed aerosol acidity in order to obtain a better understanding of the conditions leading to the formation of the dimers and how these parameters may affect the formation and chemical composition of SOA. We propose that the $\alpha$-pinene-derived dimers may arise via gas-phase reactions involving stabilized Criegee intermediates (CI) from the ozonolysis of $\alpha$-pinene rather than esterification in the aerosol phase, which is kinetically inconsistent with the experimentally observed timescale for dimer formation.

\section{Experimental}

\subsection{Smog chamber experiments}

A total of 12 sets of smog chamber experiments were performed at the University of North Carolina $274 \mathrm{~m}^{3}$ dual outdoor smog chamber facility (Pittsboro, NC), consisting of two individual chambers with identical volumes $\left(136 \mathrm{~m}^{3}\right)$ divided by a Teflon film curtain. Details of the chamber instrumentation have been described elsewhere (Lee et al., 2004; Leungsakul et al., 2005; Kamens et al., 2011; Zhang et al., 2011, 2012). During all experiments, $\mathrm{O}_{3}$ and oxides of nitrogen $\left(\mathrm{NO}_{\mathrm{x}}\right)$ were measured continuously by UV photometric (ThermoEnvironmental 49P) and chemiluminescent monitors (Bendix Model 8101B analysers), respectively. $\alpha$-Pinene concentrations were measured by gas chromatography/flame ionization detection (GC/FID, Model CP3800 , Varian). Particle size distributions and volume concentrations were measured using a scanning mobility particle sizer (SMPS) (TSI 3080) coupled with a condensation particle counter (CPC) (TSI 3022A). All SMPS data were 
corrected for wall-loss rate estimated for each individual experiment by monitoring the particle mass for approximately $2 \mathrm{~h}$ after the addition of seed particles. For each experiment, aerosol filter samples (PALL Life Sciences, Teflon, $47 \mathrm{~mm}$ diameter, $1.0 \mu \mathrm{m}$ pore size) for off-line ultra-performance liquid chromatography/electrospray ionization high-resolution quadrupole time-of-flight mass spectrometry (UPLC/ESIHR-Q-TOFMS) analysis were collected at a flow rate of $\sim 17 \mathrm{~L} \mathrm{~min}^{-1}$ from both chambers. In all experiments, background aerosol filter samples were collected from both chambers prior to the injection of $\alpha$-pinene. $\alpha$-Pinene was added to both chambers simultaneously by vapourizing a known volume of $\alpha$-pinene $(99 \%$, Aldrich) in a U-tube manifold into a $\mathrm{N}_{2}$ flow. Filter sampling of SOA from both chambers was initiated simultaneously after the aerosol volume concentration had reached its maximum value (as determined by the SMPS) and $\alpha$-pinene was no longer detectable by GC/FID. Table 1 shows the conditions for all experiments. The experiments were conducted on clear sunny days from late July through early December 2012, as reflected in the variation of temperatures for the experiments. The general procedure for experiments was as follows. Both sides of the chamber were vented with rural background air before each experiment. Drying was subsequently performed with a $250 \mathrm{~L} \mathrm{~min}^{-1}$ Aadco clean air generator at a flow rate of $6 \mathrm{~m}^{3} \mathrm{~h}^{-1}$ for a minimum of $12 \mathrm{~h}$ for each side of the chamber.

To investigate the SOA formation from $\alpha$-pinene at very low- $\mathrm{NO}_{\mathrm{x}}$ conditions, indoor chamber experiments were conducted in an indoor $10 \mathrm{~m}^{3}$ flexible Teflon chamber at the University of North Carolina (UNC) Department of Environmental Sciences and Engineering. The chamber was flushed with high-purity air from a clean air generator before the addition of seed aerosol by nebulization. As $\mathrm{NO}_{\mathrm{x}}$ had never been introduced into the indoor chamber, the concentration of $\mathrm{NO}_{\mathrm{x}}$ was expected to be below 1 ppbv during the experiments. Glass microlitre syringes were used to inject a known amount of $\alpha$-pinene into a $10 \mathrm{~mL}$ glass manifold wrapped with calibrated heating tapes. The tapes were heated to $60^{\circ} \mathrm{C}$ while flushing the manifold with high-purity $\mathrm{N}_{2}$ (preheated to $60^{\circ} \mathrm{C}$ ) at $5 \mathrm{~L} \mathrm{~min}^{-1}$ for at least $2 \mathrm{~h}$ until no additional increase in aerosol volume was observed by SMPS after which particle samples were collected on $47 \mathrm{~mm}$ diameter, $1.0 \mu \mathrm{m}$ pore size Teflon membrane filters (Pall Life Science) for product analyses, at a sampling flow rate of $\sim 20 \mathrm{~L} \mathrm{~min}^{-1}$ for $1.5 \mathrm{~h}$.

\subsection{SOA from $\alpha$-pinene ozonolysis}

All experiments involving $\mathrm{O}_{3}$-initiated oxidation of $\alpha$-pinene in the outdoor smog chamber were performed after sunset and terminated before sunrise to minimize the role of $\mathrm{OH}$ initiated oxidation. To investigate the effect of $\mathrm{O}_{3}$ level on the formation of organic acids and dimers from $\alpha$-pinene, the two individual chambers were prepared with similar RH but different $\mathrm{O}_{3}$ concentrations prior to the injection of $\alpha$-pinene (temperature and RH profiles are shown in the Supplement). Ammonium sulfate (AS) seed aerosol was added to each chamber by nebulizing a $0.06 \mathrm{M}$ AS solution and monitored for $\sim 2 \mathrm{~h}$ before the addition of an $\mathrm{OH}$-scavenger and $\mathrm{O}_{3}$. Approximately $16 \mathrm{ppm}$ of cyclohexane was added as $\mathrm{OH}-$ scavenger to each chamber. Approximately 90 and $180 \mathrm{ppb}$ of $\mathrm{O}_{3}$ was injected from an ozone generator (Model L21, Pacific Ozone) into each of the two chambers, respectively, before adding $50 \mathrm{ppb}$ of $\alpha$-pinene. No SOA formation was detected by the SMPS during the injection of $\mathrm{O}_{3}$. To investigate the role of AS seed aerosols on the particle formation following ozonolysis the experiments were repeated in the absence of AS seed.

$\alpha$-pinene ozonolysis experiments with lower SOA mass yield were performed to examine the effect of SOA mass on the formation of organic acid and dimers. Here, the two chambers were prepared with similar RH $(\sim 90 \%)$, AS seed aerosol $\left(\sim 30 \mu \mathrm{g} \mathrm{m}^{-3}\right), \mathrm{O}_{3}(\sim 70 \mathrm{ppb})$ and cyclohexane $(\sim 16 \mathrm{ppm})$ concentrations before the addition of $20 \mathrm{ppb}$ of $\alpha$-pinene to both chambers after sunset.

In addition, the effect of aerosol acidity on the formation of organic acids and dimers was also investigated. The two chambers were prepared with similar RH and injected with approximately $30 \mu \mathrm{g} \mathrm{m}^{-3}$ of seed aerosol. For acidic conditions, a solution of $0.06 \mathrm{M} \mathrm{MgSO}_{4}$ with $0.06 \mathrm{M} \mathrm{H}_{2} \mathrm{SO}_{4}$ was nebulized into the chamber. For neutral conditions, a $0.06 \mathrm{M}$ AS solution was nebulized into the chamber. Aerosol mass concentrations were monitored for $\sim 2 \mathrm{~h}$ before $\sim 90 \mathrm{ppb}$ of $\mathrm{O}_{3}$ was added to both chambers followed by the addition of $50 \mathrm{ppb}$ of $\alpha$-pinene.

$\alpha$-Pinene SOA formation under conditions with very low (below detection limit) $\mathrm{NO}_{\mathrm{x}}$ was investigated in the UNC indoor smog chamber. After the addition of $\sim 70 \mu \mathrm{g} \mathrm{m}^{-3}$ AS seed aerosol, $170 \mathrm{ppb}$ ozone was added to the chamber along with $100 \mathrm{ppb}$ of $\alpha$-pinene. The experiment was carried out in the dark at a constant temperature $\left(24-25^{\circ} \mathrm{C}\right)$ under dry ( $\mathrm{RH}<6 \%)$ conditions. No OH-scavenger was added to the chamber.

\subsection{Effect of RH on SOA from OH oxidation}

The formation of SOA from OH-initiated oxidation of $\alpha$-pinene at different $\mathrm{RH}$ was investigated in the outdoor dual chamber. Drying was performed for three days in one chamber to obtain low-RH conditions, while a high-RH atmosphere was obtained by using the clean air generator for only $1-2 \mathrm{~h}$ prior to the experiment (temperature and $\mathrm{RH}$ profiles are shown in Fig. S3 in the Supplement). SMPS measurements showed background aerosol mass concentrations less than $5 \mu \mathrm{g} \mathrm{m}^{-3}$ in the high-RH chamber and less than $2 \mu \mathrm{g} \mathrm{m}^{-3}$ in the low-RH chamber. Approximately $30 \mu \mathrm{g} \mathrm{m}^{-3}$ of seed aerosol was injected into each chamber by using a nebulizer that contained a $0.06 \mathrm{M}$ AS solution. Approximately $200 \mathrm{ppb}$ nitric oxide (NO) was then injected into both 
Table 1. Experimental conditions.

\begin{tabular}{|c|c|c|c|c|c|c|c|c|c|c|}
\hline Exp.\# & Description & Chamber & $\begin{array}{l}{[\alpha-} \\
\text { pinene }]_{0} \\
(\mathrm{ppb})\end{array}$ & $\begin{array}{l}{[\mathrm{NO}]_{0}} \\
(\mathrm{ppb})\end{array}$ & $\begin{array}{l}{\left[\mathrm{O}_{3}\right]_{0}} \\
(\mathrm{ppb})\end{array}$ & $\begin{array}{l}\text { Seed } \\
\text { Aerosol }\end{array}$ & $\begin{array}{l}\mathrm{OH}- \\
\text { scavenger }\end{array}$ & $\mathrm{RH}(\%)$ & $\begin{array}{l}\text { Temp. } \\
\left({ }^{\circ} \mathrm{C}\right)\end{array}$ & $\begin{array}{l}{[\mathrm{SOA}} \\
\operatorname{mass}]_{\max } \\
\left(\mu \mathrm{g} \mathrm{m}^{-3}\right)\end{array}$ \\
\hline \multirow[t]{2}{*}{1} & $\begin{array}{l}\text { OH oxidation under different } \\
\text { RH }\end{array}$ & A & 200 & 200 & b.d & $\left(\mathrm{NH}_{4}\right)_{2} \mathrm{SO}_{4}$ & - & 43 & 5 & 146 \\
\hline & & B & 200 & 200 & b.d & $\left(\mathrm{NH}_{4}\right)_{2} \mathrm{SO}_{4}$ & - & 93 & 4 & 138 \\
\hline \multirow[t]{2}{*}{2} & $\begin{array}{l}\text { OH oxidation under different } \\
\text { RH }\end{array}$ & A & 100 & 170 & b.d & $\left(\mathrm{NH}_{4}\right)_{2} \mathrm{SO}_{4}$ & - & 14 & 28 & 21 \\
\hline & & $\mathrm{B}$ & 100 & 150 & b.d & $\left(\mathrm{NH}_{4}\right)_{2} \mathrm{SO}_{4}$ & - & 27 & 28 & 28 \\
\hline \multirow[t]{2}{*}{3} & $\begin{array}{l}\mathrm{OH} \text { oxidation under different } \\
\mathrm{RH}\end{array}$ & A & 100 & 200 & b.d & $\left(\mathrm{NH}_{4}\right)_{2} \mathrm{SO}_{4}$ & - & 15 & 26 & 22 \\
\hline & & $\mathrm{B}$ & 100 & 190 & b.d & $\left(\mathrm{NH}_{4}\right)_{2} \mathrm{SO}_{4}$ & - & 46 & 26 & 22 \\
\hline \multirow[t]{2}{*}{4} & $\mathrm{O}_{3}$ oxidation with $\mathrm{AS}$ seed & A & 50 & b.d & 80 & $\left(\mathrm{NH}_{4}\right)_{2} \mathrm{SO}_{4}$ & cyclohexane & 80 & 10 & 69 \\
\hline & & $\mathrm{B}$ & 50 & b.d & 170 & $\left(\mathrm{NH}_{4}\right)_{2} \mathrm{SO}_{4}$ & cyclohexane & 80 & 10 & 77 \\
\hline \multirow[t]{2}{*}{5} & $\mathrm{O}_{3}$ oxidation without $\mathrm{AS}$ seed & A & 50 & b.d & 90 & No seed & cyclohexane & 77 & 15 & 59 \\
\hline & & $\mathrm{B}$ & 50 & b.d & 180 & No seed & cyclohexane & 79 & 15 & 68 \\
\hline \multirow[t]{2}{*}{6} & $\mathrm{O}_{3}$ oxidation low SOA exp. & A & 20 & b.d & 70 & $\left(\mathrm{NH}_{4}\right)_{2} \mathrm{SO}_{4}$ & cyclohexane & 90 & 12 & 26 \\
\hline & & B & 20 & b.d & 70 & $\left(\mathrm{NH}_{4}\right)_{2} \mathrm{SO}_{4}$ & cyclohexane & 90 & 12 & 28 \\
\hline 7 & $\mathrm{O}_{3}$ oxidation indoor chamber & & 100 & b.d & 170 & $\left(\mathrm{NH}_{4}\right)_{2} \mathrm{SO}_{4}$ & - & 6 & 25 & 136 \\
\hline \multirow[t]{2}{*}{8} & $\begin{array}{l}\mathrm{O}_{3} \text { oxidation under different } \\
\text { acidity }\end{array}$ & A & 50 & b.d & 80 & $\left(\mathrm{NH}_{4}\right)_{2} \mathrm{SO}_{4}$ & - & 40 & 9 & 94 \\
\hline & & B & 50 & b.d & 80 & $\begin{array}{l}\mathrm{MgSO}_{4}+ \\
\mathrm{H}_{2} \mathrm{SO}_{4}\end{array}$ & - & 40 & 9 & 78 \\
\hline \multirow[t]{2}{*}{9} & $\begin{array}{l}\mathrm{O}_{3} \text { oxidation under different } \\
\text { acidity }\end{array}$ & A & 50 & b.d & 100 & $\left(\mathrm{NH}_{4}\right)_{2} \mathrm{SO}_{4}$ & - & 93 & 11 & 63 \\
\hline & & B & 50 & b.d & 120 & $\begin{array}{l}\mathrm{MgSO}_{4}+ \\
\mathrm{H}_{2} \mathrm{SO}_{4}\end{array}$ & - & 93 & 11 & 56 \\
\hline \multirow[t]{3}{*}{10} & $\begin{array}{l}\mathrm{OH} \text { vs. } \mathrm{O}_{3} \text { oxidation under } \\
\text { different } \mathrm{RH}\end{array}$ & A & $\begin{array}{l}100 \\
+50^{*}\end{array}$ & $\begin{array}{l}250 \\
\text { b.d* }\end{array}$ & $\begin{array}{l}\text { b.d } \\
210^{*}\end{array}$ & $\left(\mathrm{NH}_{4}\right)_{2} \mathrm{SO}_{4}$ & - & $\begin{array}{l}21 \\
39^{*}\end{array}$ & $\begin{array}{l}26 \\
24^{*}\end{array}$ & $\begin{array}{l}18 \\
37^{*}\end{array}$ \\
\hline & & $\mathrm{B}$ & 100 & 230 & 0 & $\left(\mathrm{NH}_{4}\right)_{2} \mathrm{SO}_{4}$ & - & 56 & 26 & 17 \\
\hline & & & $+50^{*}$ & b.d* & $160^{*}$ & & & $68^{*}$ & $24^{*}$ & $38^{*}$ \\
\hline \multirow[t]{4}{*}{11} & $\mathrm{OH}$ vs. $\mathrm{O}_{3}$ oxidation under & A & 150 & 310 & 0 & $\left(\mathrm{NH}_{4}\right)_{2} \mathrm{SO}_{4}$ & - & 19 & 20 & 38 \\
\hline & different RH & & $+50^{*}$ & b.d* & $100^{*}$ & & & $38^{*}$ & $17^{*}$ & $64^{*}$ \\
\hline & & $\mathrm{B}$ & 150 & 300 & 0 & $\left(\mathrm{NH}_{4}\right)_{2} \mathrm{SO}_{4}$ & - & 46 & 20 & 35 \\
\hline & & & $+50^{*}$ & b.d* & $90^{*}$ & & & $73^{*}$ & $17^{*}$ & $48^{*}$ \\
\hline \multirow[t]{4}{*}{12} & $\mathrm{OH}$ vs. $\mathrm{O}_{3}$ oxidation under & A & 100 & 200 & 0 & $\left(\mathrm{NH}_{4}\right)_{2} \mathrm{SO}_{4}$ & - & 17 & 11 & 25 \\
\hline & different RH & & $+50^{*}$ & b.d* & $120^{*}$ & & & $53^{*}$ & $11^{*}$ & $50^{*}$ \\
\hline & & B & 100 & 200 & 0 & $\left(\mathrm{NH}_{4}\right)_{2} \mathrm{SO}_{4}$ & - & 56 & 11 & 25 \\
\hline & & & $+50^{*}$ & b.d* & $90^{*}$ & & & $81^{*}$ & $11^{*}$ & $50^{*}$ \\
\hline \multirow[t]{4}{*}{13} & $\mathrm{OH}$ vs. $\mathrm{O}_{3}$ oxidation under & A & 100 & 210 & 0 & $\left(\mathrm{NH}_{4}\right)_{2} \mathrm{SO}_{4}$ & - & 30 & 17 & 25 \\
\hline & different RH & & $+50^{*}$ & b.d* & $210^{*}$ & & & $49^{*}$ & $17^{*}$ & $68^{*}$ \\
\hline & & $\mathrm{B}$ & 100 & 210 & 0 & $\left(\mathrm{NH}_{4}\right)_{2} \mathrm{SO}_{4}$ & - & 64 & 17 & 24 \\
\hline & & & $+50^{*}$ & $0^{*}$ & $180^{*}$ & & & $84^{*}$ & $17^{*}$ & $64^{*}$ \\
\hline
\end{tabular}

* Data related to second injection of $\alpha$-pinene.
b.d stands for "below detection limit".

chambers from a high-pressure gas cylinder (1\% nitric oxide in nitrogen, Airgas National Welders) and allowed to stabilize. A relatively high level of NO was chosen to effectively titrate any remaining $\mathrm{O}_{3}$ left in the chambers. $100 \mathrm{ppb}$ $\alpha$-pinene was then added to both chambers simultaneously. For comparison, one experiment (experiment 1, Table 1) involved the addition of $200 \mathrm{ppb}$ of $\alpha$-pinene to both chambers.

To investigate how SOA from $\mathrm{OH}$-initiated oxidation of $\alpha$-pinene would affect further SOA formation from ozonolysis, an injection of $50 \mathrm{ppb} \alpha$-pinene was made into each chamber after sunset in four of the experiments described above. At the time of the second $\alpha$-pinene injection, there was no residual $\alpha$-pinene and the chambers contained 80-200 ppb of $\mathrm{O}_{3}$ formed from the $\mathrm{OH}$-initiated photooxida- tion of $\alpha$-pinene during the day along with the initial AS seed modified by the condensation of $\mathrm{OH}$-initiated $\alpha$-pinene oxidation products. The second injection of $\alpha$-pinene was made after sunset to minimize further oxidation by $\mathrm{OH}$.

\subsection{Filter sample extractions and UPLC/MS analysis}

SOA samples collected from chamber experiments were stored in individual pre-cleaned glass vials in a $-20^{\circ} \mathrm{C}$ freezer until extraction. Samples were extracted in $20 \mathrm{~mL}$ of high purity methanol (LC-MS CHROMASOLV-grade, Sigma-Aldrich) by sonication for $45 \mathrm{~min}$. The methanol extracts were then evaporated under a gentle flow of $\mathrm{N}_{2}$ at ambient temperature before being reconstituted in $150 \mu \mathrm{L}$ of a $50: 50(v / v)$ solvent mixture of $0.1 \%$ acetic acid in methanol 


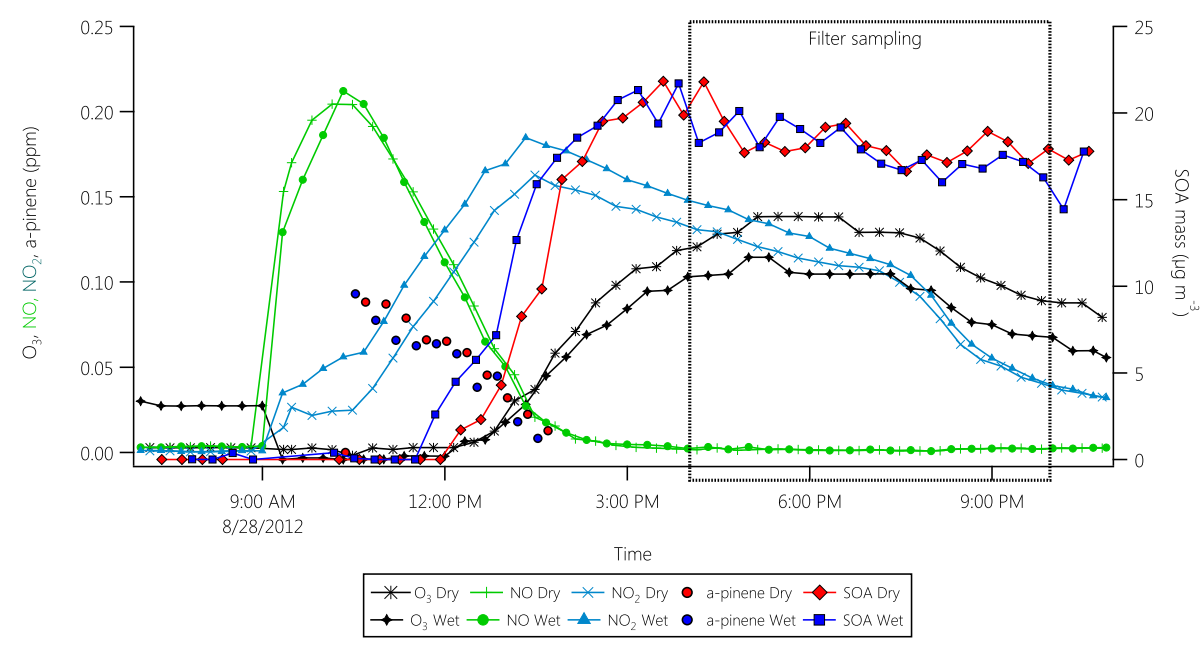

Fig. 2. Concentration of $\mathrm{NO}, \mathrm{NO}_{2}, \mathrm{O}_{3}, \alpha$-pinene (ppm) and SOA mass $\left(\mu \mathrm{g} \mathrm{m}^{-3}\right)$ in the low- (Dry) and high- (Wet) RH chamber during $\mathrm{OH}$-oxidation of $\alpha$-pinene (experiment 3, Table 1).

(LC-MS CHROMASOLV-grade, Sigma-Aldrich) and $0.1 \%$ acetic acid in water (LC-MS CHROMASOLV-grade, SigmaAldrich). The mixtures were shaken and sonicated for $5 \mathrm{~min}$ and stored at $-20{ }^{\circ} \mathrm{C}$ before analysis.

Samples were analysed using an Agilent Ultra Performance Liquid Chromatography (UPLC) coupled to the electrospray ionization (ESI) source of an Agilent 6520 Series Accurate Mass Quadrupole Time-of-Flight Mass Spectrometer (Q-TOFMS) operated in the negative $(-)$ ion mode. The operating conditions have been described in detail elsewhere (Zhang et al., 2011). Chromatograms of identified compounds are shown in Fig. S1 in the Supplement.

Organic acids and dimers identified in the extracted aerosol samples were quantified using cis-pinic acid (a diacid; Sigma-Aldrich), cis-pinonic acid and keto-pinic acid (monoacids; Sigma-Aldrich) as surrogates. Six-point calibration curves of the acid surrogates were constructed over the range $0.1-100 \mu \mathrm{g} \mathrm{mL}^{-1}$. Because authentic standards were not available, acids having two or more carboxylate groups, including pinic acid, diaterpenylic acid, diaterpenylic acid acetate (DTAA), 3-methyl-butane tricarboxylic acid (MBTCA) and the dimers, were quantified using cispinic acid, while the monoacids pinonic and hydroxy-pinonic acid were quantified using cis-pinonic acid (Table 2). Based on structural similarity, terebic acid and terpenylic acid were quantified with keto-pinic acid. UPLC/ESI-HR-Q-TOFMS analysis of all background aerosol filters collected from each set of experiments indicated that both chambers were free of $\alpha$-pinene SOA constituents prior to injection of $\alpha$-pinene.

\section{Results and discussion}

\subsection{OH-initiated oxidation of $\alpha$-pinene: effect of RH}

The results of the investigation of $\mathrm{OH}$-initiated oxidation of $\alpha$-pinene under initially high NO concentrations and different RH conditions are shown in Figs. 2-4. Figure 2 shows the time dependence of concentrations of $\mathrm{NO}, \mathrm{NO}_{2}$, $\mathrm{O}_{3}, \alpha$-pinene and SOA. The concentration of $\mathrm{NO}$ decreases by reaction between $\mathrm{NO}$ and alkyl peroxy radicals $\left(\mathrm{RO}_{2}\right)$ formed from $\mathrm{OH}$-initiated oxidation during the day following an initial injection of $100 \mathrm{ppb} \alpha$-pinene to both chambers (e.g. Arey et al., 2001). Once sufficient $\mathrm{NO}_{2}$ has been formed, photolysis of $\mathrm{NO}_{2}$ initiates $\mathrm{O}_{3}$ formation in the chambers. Prior to the increase in $\mathrm{O}_{3}$ concentration, most of the injected $\alpha$-pinene has been consumed by reaction with $\mathrm{OH}$, with the formation of $21-22 \mu \mathrm{g} \mathrm{m}^{-3}$ of SOA under lowRH (14-15\% initial $\mathrm{RH})$ conditions and $22-28 \mu \mathrm{g} \mathrm{m}^{-3}$ under high-RH (27-46\% initial RH) conditions (experiments 2 and 3, Table 1).

The aerosol size distribution plots during $\mathrm{OH}$-initiated oxidation of $\alpha$-pinene under conditions of high and low $\mathrm{RH}$ are given in Fig. 3. The particle number concentration decreases as the particles grow in size due to condensation, coagulation and particle wall loss to the surface of the chamber, resulting in a shift in the mode to $\sim 170 \mathrm{~nm}$ at the end of the experiment with no significant difference in the particle size distributions between high and low RH. A similar observation was reported by Bonn et al. (2002) for the $\mathrm{OH}$-initiated oxidation of $\beta$-pinene.

Figure 4 shows the concentration of oxidation products from the $\mathrm{OH}$-initiated oxidation of $\alpha$-pinene under highand low-RH conditions at different $\alpha$-pinene concentrations (200 ppb vs. 100 ppb, experiments 1-3, Table 1). Experiments with low $\alpha$-pinene concentrations (100 ppb) show a 
Table 2. Overview of compounds investigated in this study. References: (1) Claeys et al. (2009); (2) Yasmeen et al. (2010); (3) Szmigielski et al. (2007); (4) Gao et al. (2010).

\begin{tabular}{|c|c|c|c|}
\hline Compound (reference) & Suggested molecular structure & Molecular formula & {$[\mathrm{M}-\mathrm{H}]^{-}$ion $(m / z)$} \\
\hline Terebic acid ${ }^{2}$ & & $\mathrm{C}_{7} \mathrm{H}_{10} \mathrm{O}_{4}$ & 157.050 \\
\hline Pinonic acid & & $\mathrm{C}_{10} \mathrm{H}_{16} \mathrm{O}_{3}$ & 183.101 \\
\hline Hydroxy-pinonic acid (OH-pinonic acid) & & $\mathrm{C}_{10} \mathrm{H}_{16} \mathrm{O}_{4}$ & 199.104 \\
\hline Pinic acid & & $\mathrm{C}_{9} \mathrm{H}_{14} \mathrm{O}_{4}$ & 185.080 \\
\hline Terpenylic acid ${ }^{1}$ & & $\mathrm{C}_{8} \mathrm{H}_{12} \mathrm{O}_{4}$ & 171.065 \\
\hline Diaterpenylic acid ${ }^{2}$ (DTA) & & $\mathrm{C}_{8} \mathrm{H}_{14} \mathrm{O}_{5}$ & 189.190 \\
\hline 3-Methyl-1,2,3-butanetricarboxylic acid ${ }^{3}$ (MBTCA) & & $\mathrm{C}_{8} \mathrm{H}_{12} \mathrm{O}_{6}$ & 203.055 \\
\hline Diaterpenylic acid acetate ${ }^{1}$ (DTAA) & & $\mathrm{C}_{10} \mathrm{H}_{16} \mathrm{O}_{6}$ & 231.086 \\
\hline Pinyl-diaterebyl ester ${ }^{2}$ MW 344 & & $\mathrm{C}_{16} \mathrm{H}_{24} \mathrm{O}_{8}$ & 343.139 \\
\hline Pinyl-diaterpenyl ester ${ }^{2}$ MW 358 & & $\mathrm{C}_{17} \mathrm{H}_{26} \mathrm{O}_{8}$ & 357.156 \\
\hline Pinonyl-pinyl ester ${ }^{2}$ MW 368 & & $\mathrm{C}_{19} \mathrm{H}_{28} \mathrm{O}_{7}$ & 367.175 \\
\hline MW 388 dimer ester ${ }^{4}$ & Unknown & $\mathrm{C}_{18} \mathrm{H}_{28} \mathrm{O}_{9}$ & 387.166 \\
\hline
\end{tabular}

clear dependence on $\mathrm{RH}$, with the formation of higher relative concentrations of almost all acids under dry conditions (RH 14-15\%). The dominant acids in the low $\alpha$-pinene experiments are MBTCA and DTAA, which account for about 5 and $3 \%$, respectively, of the total SOA mass. Experiments performed with higher $\alpha$-pinene concentrations
(200 ppb) show a much less pronounced effect of RH on the acid concentrations. However, the probable explanation for this observation is that the high-concentration $\alpha$-pinene experiments were performed during late October at much lower ambient temperatures $\left(\sim 5^{\circ} \mathrm{C}\right)$, so the difference between high-RH $(43 \%)$ and low-RH $(\sim 15 \%)$ conditions was 


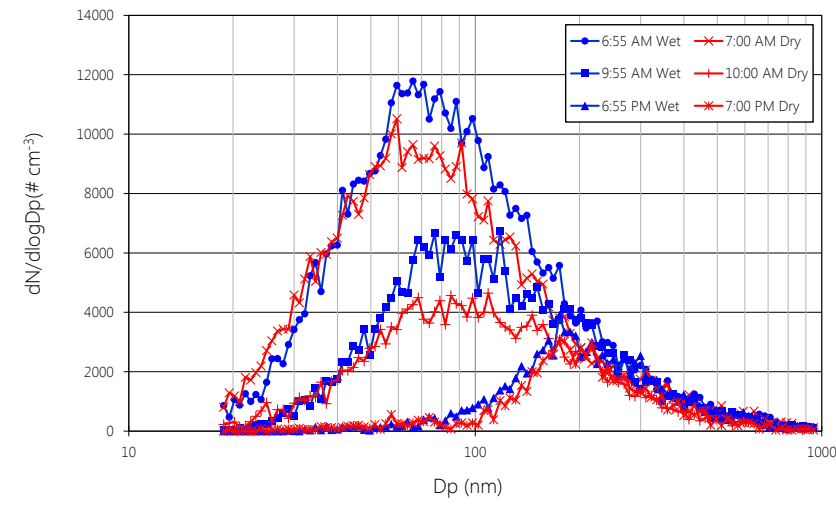

Fig. 3. Particle size distributions in high- $(15 \%$, blue) and low(46\%, red) $\mathrm{RH}$ chamber during the $\mathrm{OH}-$ and ozone-initiated oxidation experiments (experiment 3 , Table 1 ).

more pronounced for low concentration $\alpha$-pinene experiments. In addition, increased condensation at the lower ambient temperatures during the high-concentration $\alpha$-pinene experiments could partly explain the generally higher concentration of acids relative to the low concentration $\alpha$-pinene experiments. Increased condensation of pinonic acid from the gas-phase during experiments at lower ambient temperatures would also contribute to the significantly lower MBTCA concentration, since less pinonic acid would be available for $\mathrm{OH}$-initiated oxidation in the gas phase (Szmigielski et al., 2007). Furthermore, as the low concentration $\alpha$-pinene experiments were performed on clear sunny days in July-September, higher $\mathrm{OH}$ concentrations would explain the significantly higher MBTCA concentration during these experiments relative to the high-concentration $\alpha$-pinene experiments performed in late October. Although precursors suggested in previous studies (i.e. pinic acid, terpenylic acid and DTAA; Yasmeen et al., 2010) for the dimers are present in the aerosols generated in $\mathrm{OH}$-initiated oxidation experiments, no dimers were observed.

\subsection{Ozonolysis of $\alpha$-pinene: effect of $\mathrm{O}_{3}$ concentration}

Figure 5 shows the $\mathrm{NO}, \mathrm{NO}_{2}, \mathrm{O}_{3}, \alpha$-pinene and $\mathrm{SOA}$ data from an AS seeded ozonolysis experiment (experiment 4, Table 1) in which the effect of $\mathrm{O}_{3}$ level on the formation of dimers was examined. As no $\mathrm{NO}$ was added to the outdoor chamber, concentrations of $\mathrm{NO}$ and $\mathrm{NO}_{2}$ were close to the detection limit of the $\mathrm{NO}_{\mathrm{x}}$ monitor during the entire experiment. Once $\alpha$-pinene is injected into the two outdoor chambers, $\mathrm{O}_{3}$ concentration drops and SOA formation is initiated. Due to a higher $\mathrm{O}_{3}$-to- $\alpha$-pinene ratio, the rate of SOA formation is much higher in the high- $\mathrm{O}_{3}$ chamber relative to the low $\mathrm{O}_{3}$ chamber. The higher SOA formation rate is also evident in the particle size distribution data collected from both chambers during both seeded and non-seeded experiments
(Fig. 6a and b), showing higher particle number concentration in the high- $\mathrm{O}_{3}$ chambers.

The UPLC/ESI-HR-Q-TOFMS analysis of ozonolysis SOA in Fig. 7 shows only small differences in the chemical composition between the seeded and non-seeded experiments. Overall, the $\mathrm{O}_{3}$-initiated oxidation of $\alpha$-pinene results in several carboxylic acids, with pinic acid being dominant, followed by terpenylic and hydroxy-pinonic acids $(\sim 3.2 \%$, $2 \%$ and $1.8 \%$ of SOA mass, respectively). Four dimers were identified in SOA generated during ozonolysis of $\alpha$-pinene: pinyl-diaterebyl dimer (MW 344), pinyl-diaterpenyl dimer (MW 358), pinonyl-pinyl dimer (MW 368) and a dimer with MW 388 previously observed by Gao et al. (2010). The MS/MS spectrum of the MW 388 dimer is shown in Fig. S2 in the Supplement. Pinyl-diaterpenyl dimer is the dominant dimer, constituting about $1 \%$ of the SOA mass. Relative to $\mathrm{OH}$-initiated oxidations, the concentration of the secondgeneration $\mathrm{OH}$-oxidation product MBTCA is significantly lower in the $\mathrm{O}_{3}$-initiated oxidation experiments because of the absence of $\mathrm{OH}$ during night-time and added $\mathrm{OH}$ scavenger. In addition, almost no DTAA is formed during the dark ozonolysis of $\alpha$-pinene indicating that DTAA is formed only in the presence of OH-radicals. This result supports the formation through $\mathrm{OH}$-initiated oxidation of $\alpha$-pinene as suggested by Claeys et al. (2009) based on the formation pathway reported in the theoretical study by Vereecken et al. (2007). The four dominant carboxylic acids (pinic acid, terpenylic acid, hydroxy-pinonic acid and pinonic acid) show a slightly higher concentration in SOA sampled from the high- $\mathrm{O}_{3}$ chamber. In addition, pinyl-diaterpenyl dimer (MW 358) and the MW 388 dimer also show increased concentration with the higher $\mathrm{O}_{3}$ level, indicating that elevated $\mathrm{O}_{3}$ concentration may increase the formation of these compounds from ozonolysis of $\alpha$-pinene.

\subsection{Effect of SOA mass on dimer formation}

Table 1 and Figs. 2 and 5 reveal that the addition of $50 \mathrm{ppb}$ $\alpha$-pinene to the chambers in $\mathrm{O}_{3}$-initiated oxidation experiments yields a significantly higher SOA mass than $\mathrm{OH}-$ oxidation of $100 \mathrm{ppb} \alpha$-pinene. Any effect of increased SOA mass on the formation of dimer is ruled out by Fig. 8 which presents the UPLC/ESI-HR-Q-TOFMS analysis of SOA filter samples collected from the outdoor dual chamber during the low- $\left(30 \mu \mathrm{g} \mathrm{m}^{-3}\right)$ and high- $\left(60 \mu \mathrm{g} \mathrm{m}^{-3}\right) \mathrm{SOA}-$ mass ozonolysis experiments and low- $\left(30 \mu \mathrm{g} \mathrm{m}^{-3}\right)$ and high$\left(140 \mu \mathrm{g} \mathrm{m}^{-3}\right)$ SOA-mass OH-oxidation experiments. As described earlier, the large differences in acid concentrations between the high- and low-SOA-mass OH-oxidation experiments are explained by the differences in temperature and possibly $\mathrm{OH}$ levels.

Figure 8 also shows the UPLC/ESI-HR-Q-TOFMS data from the $\alpha$-pinene ozonolysis experiment conducted in the indoor chamber (Fig. S6, time-dependent SOA formation and $\mathrm{O}_{3}$ concentration). The chemical composition of the SOA 


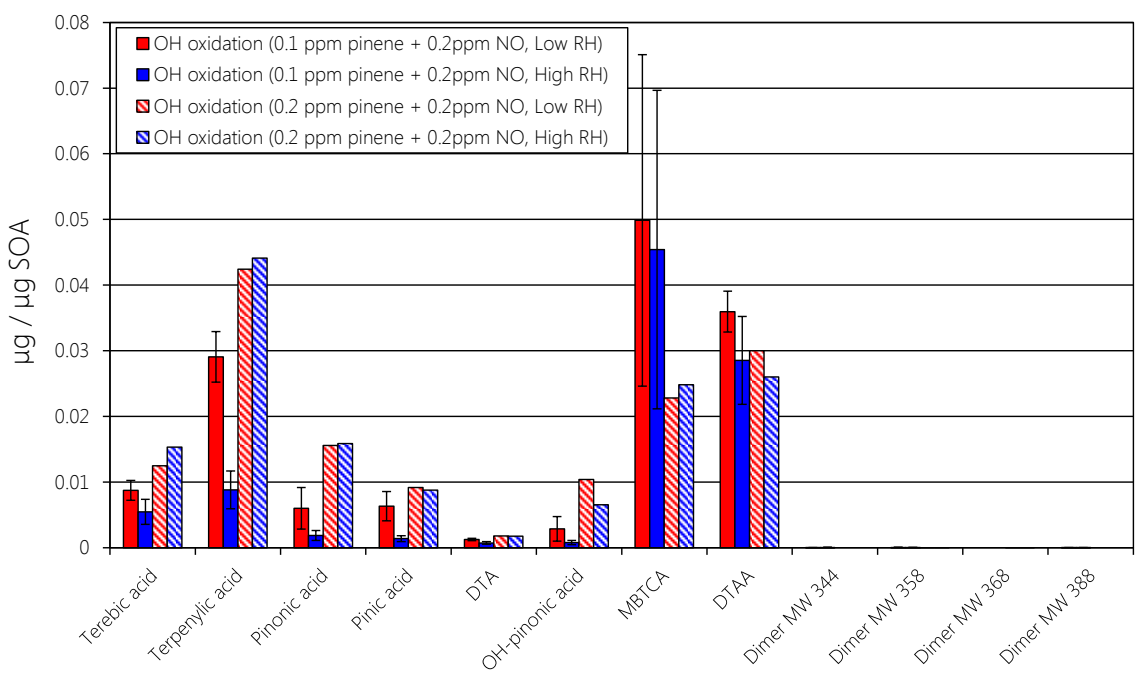

Fig. 4. Normalized concentrations ( $\mu \mathrm{g} \mu \mathrm{g}^{-1} \mathrm{SOA}$ ) of oxidation products from the OH-oxidation of $\alpha$-pinene at low (red) and high (blue) RH and at different $\alpha$-pinene concentrations (200 ppb and $100 \mathrm{ppb}$ ) (experiments $1-3$, Table 1). Standard deviations are indicated by error bars. Large standard deviations are primarily explained by differences in temperatures between experiments (see text).

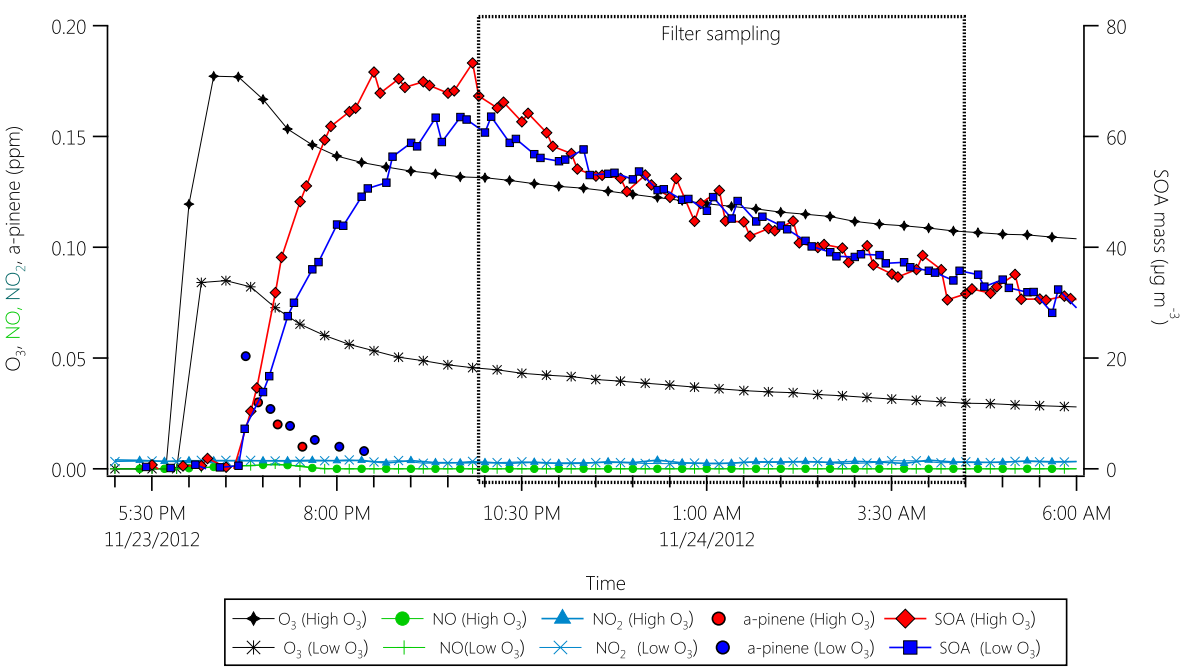

Fig. 5. Concentration of $\mathrm{NO}, \mathrm{NO}_{2}, \mathrm{O}_{3}, \alpha$-pinene (ppm) and SOA mass $\left(\mu \mathrm{g} \mathrm{m}^{-3}\right)$ in the low- $(80 \mathrm{ppb}$, blue $)$ and high- (170 ppb, red) ozone chamber (experiment 4, Table 1).

$\left(140 \mu \mathrm{g} \mathrm{m}^{-3}\right)$ is similar to that for SOA collected from the outdoor dual chamber ozonolysis experiments, once again demonstrating that increased SOA mass does not facilitate the formation of the dimers from $\alpha$-pinene. In addition, since the indoor chamber experiment is conducted at very low $\mathrm{NO}_{\mathrm{x}}$ conditions, it is concluded that the formation of dimers proceeds without the presence of $\mathrm{NO}_{\mathrm{x}}$, in line with previous investigations (Kristensen et al., 2013).

From Fig. 8 it is clear that the formation of the four dimers occurs only during $\mathrm{O}_{3}$-initiated oxidation of $\alpha$-pinene. Only small differences in yield are observed in the low- and highSOA-mass $\mathrm{O}_{3}$-initiated oxidations, indicating that the formation of the dimers in the ozonolysis experiment in Fig. 7 is not due to higher SOA mass. The slightly higher relative concentration of pinyl-diaterpenyl dimer (MW 358) and the MW 388 dimer in the low-SOA experiment (Fig. 8) can be explained by the higher ozone-to-pinene ratio, consistent with a similar effect in the high- and low- $\mathrm{O}_{3}$-level experiments (Fig. 7).

\subsection{Effect of aerosol acidity on ozonolysis}

The concentration of diaterpenylic acid (DTA) is low $(<0.2 \%$ of SOA mass $)$ in all experiments. Since DTA is tentatively proposed as a precursor of the pinyl-diaterpenyl dimer (MW 358) (Yasmeen et al., 2010), one would expect 
A

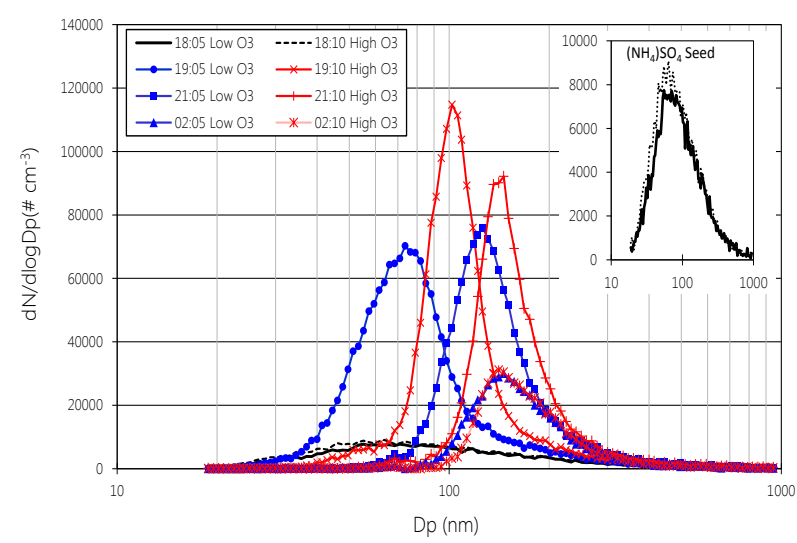

$\mathrm{B}$

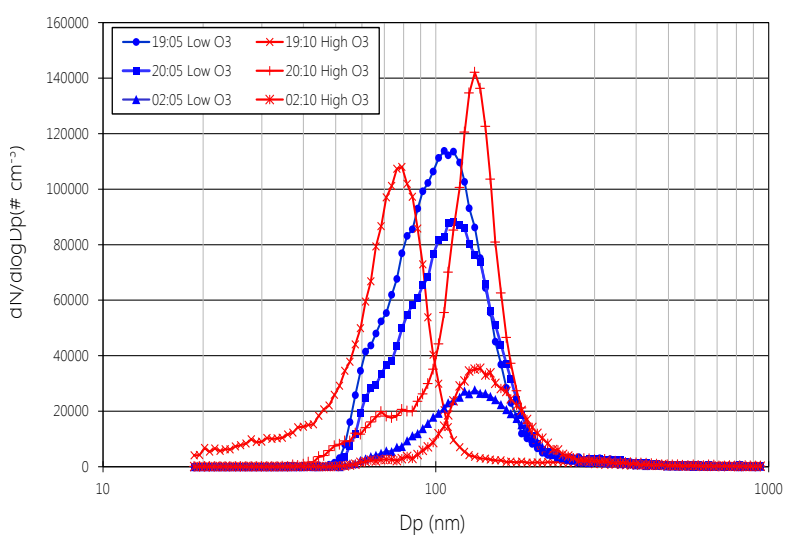

Fig. 6. (A) Particle size distributions in low- (80 ppb, blue) and high- (170 ppb, red) ozone chamber following the injection of $\alpha$-pinene (50 ppb), along with the size distribution of AS seed particles prior to the injection (black) (experiment 4, Table 1). (B) Particle size distributions in low- $(90 \mathrm{ppb}$, blue) and high- (180 ppb, red) ozone chamber following the injection of $\alpha$-pinene (50 ppb) without the addition of AS seed (experiment 5, Table 1).

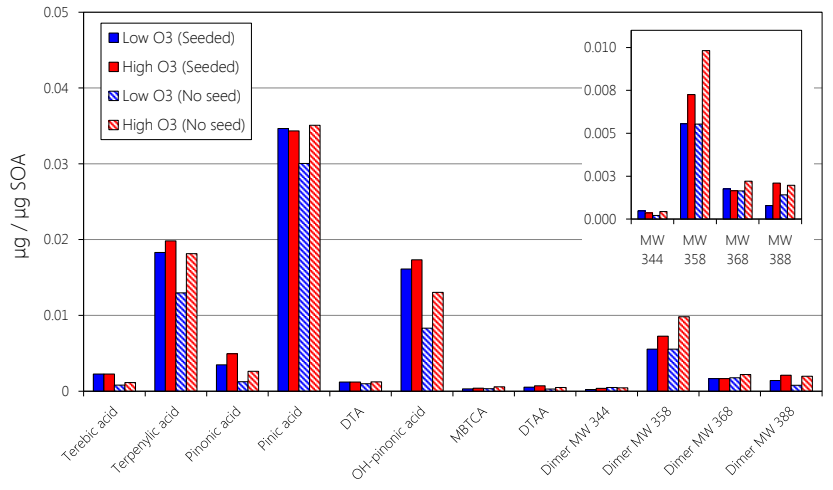

Fig. 7. Normalized concentrations $\left(\mu \mathrm{g} \mu \mathrm{g}^{-1} \mathrm{SOA}\right)$ of oxidation products from the ozonolysis of $\alpha$-pinene $(50 \mathrm{ppb})$ at low ( 80-90 ppb, blue) and high ( $\sim 170-180 \mathrm{ppb}$, red) ozone levels with and without AS seed (experiments 4-5, Table 1).

these compounds to be closely correlated. The low concentration of DTA could therefore be hypothesized to explain the relatively low yield of the dimer (0-1.6\% of SOA mass) relative to carboxylic acids (7-12\% of SOA mass) in all experiments.

If DTA were formed through the acid-catalysed hydrolysis of terpenylic acid, increased aerosol acidity would be predicted to enhance the formation of DTA, and thus, pinyldiaterpenyl dimer formation, especially if the mechanism of dimer formation was aerosol-phase esterification. Figure 9 shows the NO, $\mathrm{NO}_{2}, \mathrm{O}_{3}, \alpha$-pinene and SOA data from experiment 9 (Table 1) in which the effect of acidity on dimer formation was investigated. After the injection of $\alpha$-pinene, the SOA mass increases simultaneously in both chambers, reaching a maximum of 94 and $78 \mu \mathrm{g} \mathrm{m}^{-3}$ in the neutral and acidic chambers, respectively. Figure 10 shows the particle number size distribution of aerosol from the acidic and neutral chambers during the experiments. Prior to the injection of $\alpha$-pinene, the seed concentration, particle size distributions in the acidic and neutral chambers are similar. However, once $\alpha$-pinene is injected, a significantly higher particle number is produced under neutral conditions than under acidic conditions. In addition, particle growth under neutral conditions is significantly more rapid than under acidic conditions.

Despite differences in the SOA mass yield under acidic and neutral conditions, UPLC/ESI-HR-Q-TOFMS analysis shows similar relative concentrations of acids, including DTA, and dimers (Fig. 11). Our finding that formation of DTA is not enhanced under acidic conditions calls into question the proposed acid-catalysed formation of this compound (Claeys et al., 2009). Based on the results, DTA and DTAA do not seem to be correlated and probably originate via different routes. In addition, increased aerosol acidity does not seem to enhance the formation of the dimers significantly. These results are in accordance with the finding by Gao et al. (2004) that pre-existing seed was not required for the formation of oligomers and that aerosol acidity did not result in a significant increase in the intensities of smaller oligomers, such as the MW 358 dimer.

\subsection{Effect of $\mathrm{OH}, \mathrm{O}_{3}$ and $\mathrm{RH}$}

The results of the investigation of $\mathrm{OH}$-initiated oxidation followed by $\mathrm{O}_{3}$-initiated oxidation of $\alpha$-pinene at different RH are summarized in Figs. 12-14. Figure 12 shows the time dependence of concentrations of $\mathrm{NO}, \mathrm{NO}_{2}, \mathrm{O}_{3}$ and $\alpha$-pinene. The first injection resulted in the formation of $18-38 \mu \mathrm{g} \mathrm{m}^{-3}$ of SOA under low-RH (17-30\%) conditions and $17-35 \mu \mathrm{g} \mathrm{m}^{-3}$ under high-RH conditions (46-64\%) following the $\mathrm{OH}$-initiated oxidation of approximately $100 \mathrm{ppb}$ of $\alpha$-pinene (experiments 10-13, Table 1). As observed 


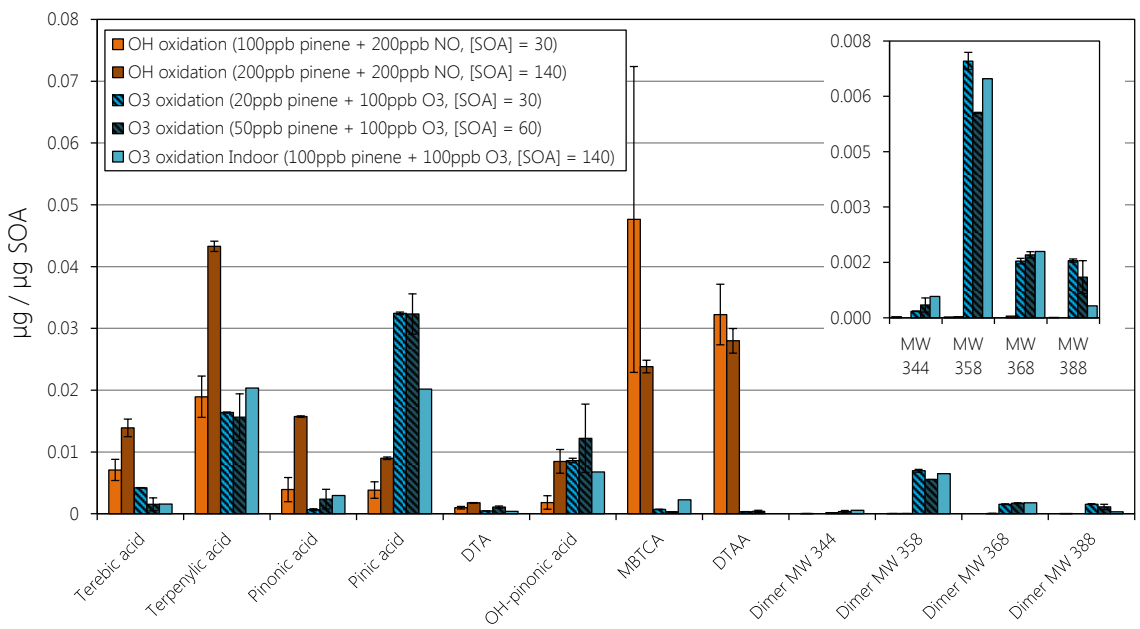

Fig. 8. Normalized concentrations ( $\mu \mathrm{g} \mathrm{gg}^{-1} \mathrm{SOA}$ ) of oxidation products from the OH-oxidation and ozonolysis of $\alpha$-pinene in both outdoor and indoor chambers at high- $\left(\sim 140 \mu \mathrm{g} \mathrm{m}^{-3}\right.$ and $60 \mu \mathrm{g} \mathrm{m}^{-3}$, experiments 1,7 and 4$)$, and low- $\left(\sim 30 \mu \mathrm{g} \mathrm{m}^{-3}\right.$, experiments $2-3$ and 6$)$ SOA-mass conditions.

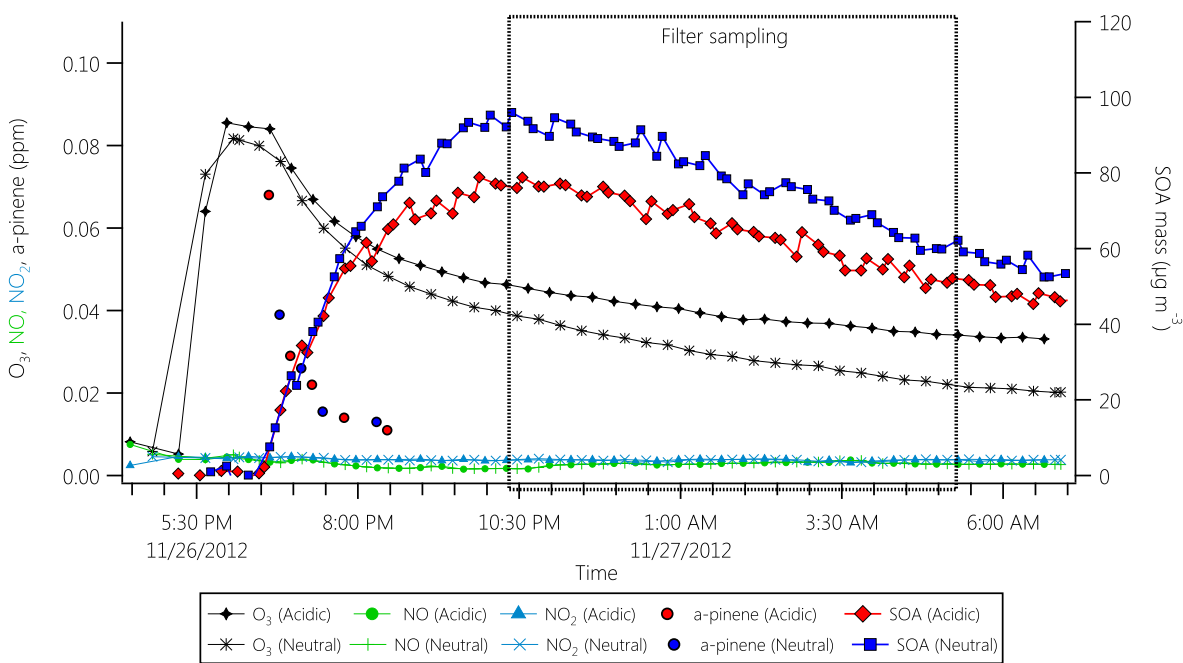

Fig. 9. Concentration of $\mathrm{NO}, \mathrm{NO}_{2}, \mathrm{O}_{3}, \alpha$-pinene (ppm) and SOA mass $\left(\mu \mathrm{g} \mathrm{m}^{-3}\right)$ in the neutral $(\mathrm{AS}$ seed, blue $)$ and acidic $\left(\mathrm{MgSO}_{4}+\mathrm{H}_{2} \mathrm{SO}_{4}\right.$ seed, red) chamber (experiment 9, Table 1).

in individual $\mathrm{OH}$ - and $\mathrm{O}_{3}$-initiated oxidation experiments (Figs. 2 and 5), although only $50 \mathrm{ppb}$ of $\alpha$-pinene is added during the second injection following sunset, the formation of SOA from ozonolysis is more rapid and yields higher SOA concentrations, ranging from 37 to 68 and $35-64 \mu \mathrm{g} \mathrm{m}^{-3}$ of SOA in the low- and high-RH chambers, respectively. Saathoff et al. (2009) have reported a negative temperature dependence of SOA yields from ozonolysis of $\alpha$-pinene, and thus the lower temperature during the second injection in our experiments might contribute to a higher production of SOA mass during nighttime. As shown in Table 1, SOA formation under both high- and low-RH conditions is similar in all experiments with oxidation by either $\mathrm{OH}$ or $\mathrm{O}_{3}$, indicating that the RH has minimal effect on the SOA mass yield from both oxidants.

The aerosol size distributions during $\mathrm{OH}$-initiated oxidation following the first $\alpha$-pinene injection under conditions of high and low RH are given in Fig. 13a and following the second $\alpha$-pinene injection in Fig. 13b. Figure 13b shows that following the second injection of $\alpha$-pinene and ozonolysis, the particle size distribution in both chambers changes significantly. In the low-RH chamber, the mode shifts from $170 \mathrm{~nm}$ (the end point of the $\mathrm{OH}$-initiated oxidation experiment) to around $300 \mathrm{~nm}$, indicating an increased SOA growth due to condensation of ozonolysis oxidation products onto pre-existing particles. In the high-RH chamber, the particle size generally increases, but distribution appears bimodal in 


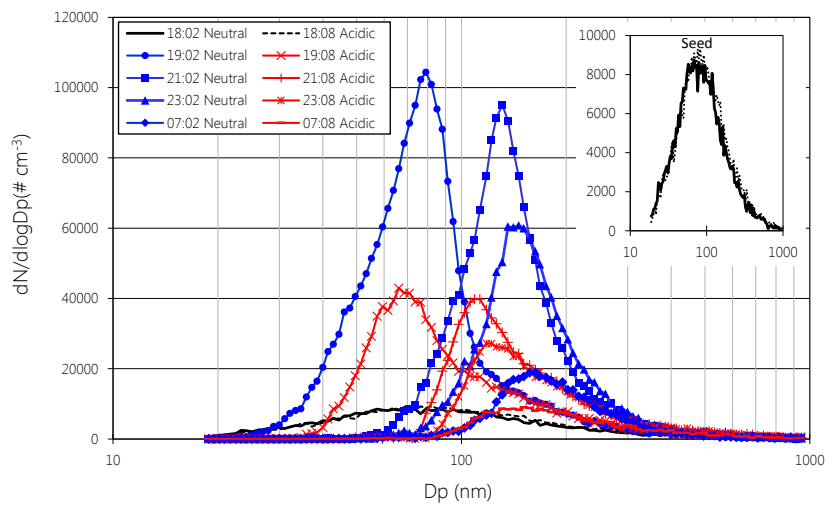

Fig. 10. Particle size distributions in neutral (AS seed, blue) and acidic $\left(\mathrm{MgSO}_{4}+\mathrm{H}_{2} \mathrm{SO}_{4}\right.$ seed, red) chamber following the injection and ozonolysis of $\alpha$-pinene along with size distribution of seed particles prior to the injection (black) (experiment 9, Table 1).

character, with the smaller diameter particles predominating. The significant increase in concentration of smaller particles $\left(D_{\mathrm{p}}<300 \mathrm{~nm}\right)$ would be indicative of new particle formation under high-RH conditions due to nucleation following the $\mathrm{O}_{3}$-initiated oxidation of $\alpha$-pinene. The number concentration of particles with diameters between 10 and $300 \mathrm{~nm}$ produced from ozonolysis of $\alpha$-pinene has been reported to increase at higher RH and has been ascribed to the presence of water vapour affecting the rate of production or the character of the nucleation species (Jonsson et al., 2006).

As described above, ozonolysis following a second injection of $\alpha$-pinene into the high-RH chamber containing $\alpha$-pinene SOA from $\mathrm{OH}$-initiated oxidation resulted in an increase in concentration to $\sim 8500$ particles $\mathrm{cm}^{-3}$ (Fig. 13b). $\mathrm{O}_{3}$-initiated oxidation of $\alpha$-pinene with pure AS as the pre-existing seed aerosol resulted in an increase to $\sim 120000$ particles $\mathrm{cm}^{-3}$ (Fig. 6a). The $\sim 14$-fold increase in total particle number suggests that seed composition could significantly affect new particle formation. Although pure AS seed particles initially have a smaller mode $(\sim 70 \mathrm{~nm})$ than seed particles from the $\mathrm{OH}$-oxidation of $\alpha$-pinene $(\sim 170 \mathrm{~nm})$, the total surface area of $\alpha$-pinene SOA-coated AS particles from OH oxidation $\left(2.2 \times 10^{8} \mathrm{~nm}^{2} \mathrm{~cm}^{-3}\right)$ is lower than that of the pure AS seed $\left(4.2 \times 10^{8} \mathrm{~nm}^{2} \mathrm{~cm}^{-3}\right)$. Thus, the aerosol from $\mathrm{OH}$ oxidation of $\alpha$-pinene does not appear to suppress nucleation by virtue of increased partitioning of ozonolysis products onto a larger total surface area. The smaller increase in particle formation observed in Fig. 13b relative to pure AS seed in Fig. 6a could be explained by the presence of an organic surface film consisting of products of $\mathrm{OH}$-initiated $\alpha$-pinene oxidation on the aqueous AS droplets initially present. As new SOA is formed from the second injection of $\alpha$-pinene, the organic film could allow for increased condensation of nucleated species, thus reducing the formation of new particles through nucleation. A similar effect has been observed by Kamens et al. (2011),

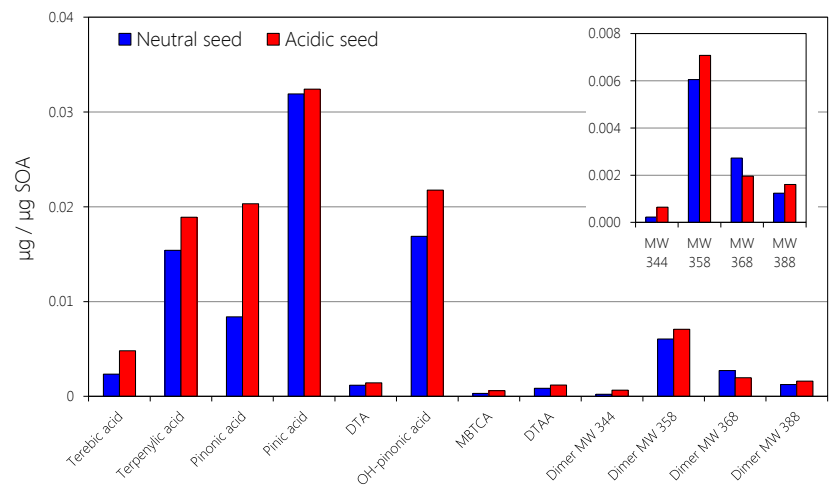

Fig. 11. Normalized concentrations $\left(\mu \mathrm{g} \mu \mathrm{g}^{-1} \mathrm{SOA}\right)$ of oxidation products from the ozonolysis of $\alpha$-pinene at neutral (AS seed, blue) and acidic $\left(\mathrm{MgSO}_{4}+\mathrm{H}_{2} \mathrm{SO}_{4}\right.$ seed, red) conditions. Two experiments were performed (experiments 8-9, Table 1).

who showed that higher initial seed aerosol from background rural air reduced the nucleation of particles from photooxidation of toluene in an urban hydrocarbon environment with $\mathrm{NO}_{\mathrm{x}}$ in natural sunlight. Increased condensation of SOA onto the organic-coated seed aerosol might also be explained by differences in viscosity. As SOA from the $\mathrm{OH}$-initiated oxidation $\alpha$-pinene condenses onto the AS seed aerosol, water uptake by the seed aerosol is enhanced. Prenni et al. (2001) found that some carboxylic acids retain water to very low RH and Cruz and Pandis (2000) found that glutaric acid and pinonic acid, in general, enhance water sorption of AS. The increased water uptake by AS due to the presence of organics, such as the carboxylic acids identified in this study, reduces the viscosity of the particles allowing newly formed SOA to partition more effectively into the pre-existing particles (Renbaum-Wolff et al., 2013). The increased partitioning of the gas-phase oxidation products to the particles results in a lowering of the concentration of gas-phase compounds required for nucleation, hence reducing the formation of new particles, consistent with Fig. 13b.

To confirm that the large increase in particle formation observed in the ozonolysis of $\alpha$-pinene in the presence of pure uncoated AS seeds arises from nucleation, ozonolysis of identical concentrations of $\alpha$-pinene was carried out without the addition of AS seed particles. Figure $6 \mathrm{~b}$ shows the particle size distribution for the chamber ozonolysis of identical concentrations of $\alpha$-pinene without pre-existing AS seed particles at high $(\sim 180 \mathrm{ppb})$ and low $(\sim 90 \mathrm{ppb}) \mathrm{O}_{3}$ levels. Even in the absence of AS seed aerosol, ozonolysis of $\alpha$-pinene results in significantly higher SOA mass and particle number concentration compared to the experiments involving $\alpha$-pinene SOA-coated AS seed (Fig. 13b). Furthermore, higher particle number concentration is observed in the non-seeded ozonolysis experiment (Fig. 6b) compared to the AS seeded experiment (Fig. 6a), indicating that the presence of AS seed reduces the particle number 


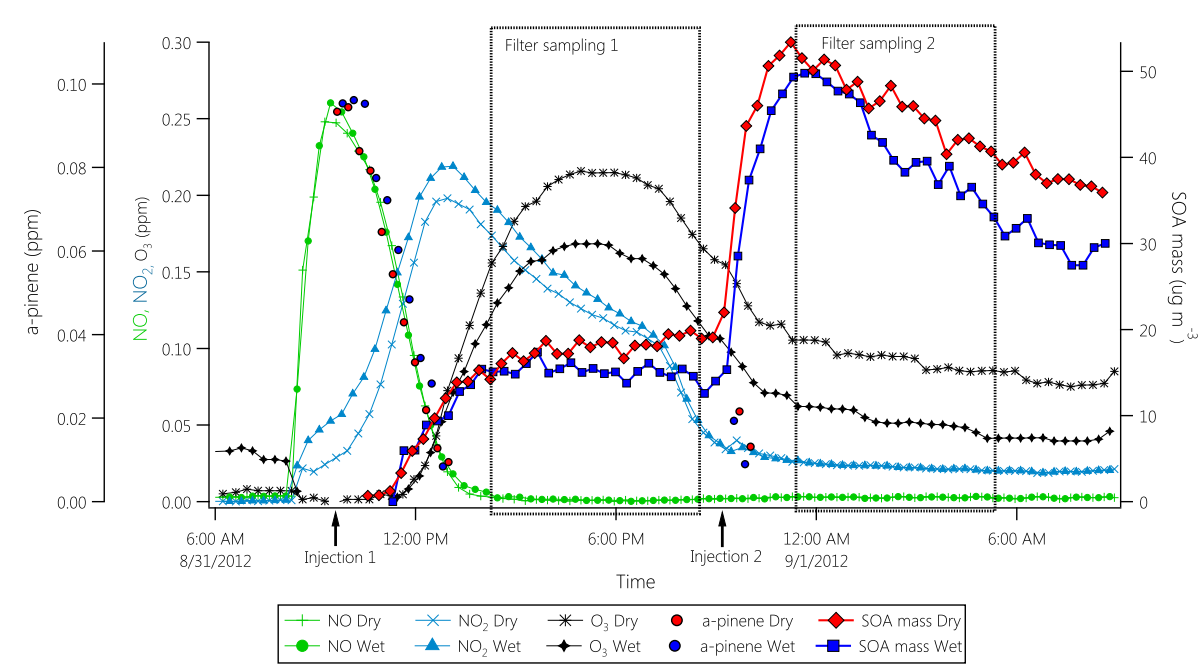

Fig. 12. Concentration of $\mathrm{NO}, \mathrm{NO}_{2}, \mathrm{O}_{3}, \alpha$-pinene (ppm) and SOA mass $\left(\mu \mathrm{g} \mathrm{m}^{-3}\right)$ in the low- (Dry) and high- (Wet) RH chamber during initial $\mathrm{OH}$ oxidation of $\alpha$-pinene followed by oxidation of a second injection of $\alpha$-pinene by $\mathrm{O}_{3}$ generated during initial oxidation (experiment 10 , Table 1). Filter sampling 1 and 2 designates SOA sampling after the first (100 ppb) and second (50 ppb) injection of $\alpha$-pinene, respectively (indicated by arrows).

from $\alpha$-pinene ozonolysis, likely due to increased condensation. Thus, pure AS seed does not facilitate particle formation from $\alpha$-pinene ozonolysis, and does not explain the increased particle formation relative to ozonolysis in the presence of SOA that is generated by the condensation of $\mathrm{OH}-$ oxidation of $\alpha$-pinene on AS. By comparison, it is clear that the SOA-coated AS particles present in the chamber after OH-oxidation of $\alpha$-pinene (Fig. 13) result in a significant greater decrease in particle number concentration following $\alpha$-pinene ozonolysis than that of pure AS (Fig. 6a). This indicates that the pure AS seed aerosol may be less effective in absorbing SOA than AS particles coated with $\alpha$-pinene SOA. The lower affinity of the $\alpha$-pinene oxidation products for the pure AS seed aerosol limits the condensation of organics in the aerosol phase resulting in an increased gas-phase concentration of oxidation products ultimately leading to the formation of new particles through nucleation, which may explain the $\sim 14$-fold higher particle number concentration observed in the pure AS ozonolysis experiments (Fig. 6a).

Another explanation for the decreased particle formation observed during the second injection of $\alpha$-pinene compared to the pure AS ozonolysis experiments could be the presence of organic acids in the gas phase. Kamens et al. (2005) showed that the presence of formic acid resulted in a decreased particle number concentration during ozonolysis of $\alpha$-pinene and assigned this to the scavenging of sCI in the gas phase by formic acid.

Figure 14 shows the relative concentration of acids and dimers observed in aerosols from the experiments in which ozonolysis occurred following the injection of $\alpha$-pinene after the depletion of $\alpha$-pinene by OH oxidation. Similar to the observation in Fig. 4, SOA that formed under low-RH con- ditions from the $\mathrm{OH}$-initiated oxidation of $\alpha$-pinene shows a higher concentration of organic acids, such as pinonic acid, hydroxy-pinonic acid, terpenylic acid and pinic acid, compared to SOA formed under high-RH conditions. A higher concentration of organic acids in the gas phase in the low- $\mathrm{RH}$ chamber prior to the second injection of $\alpha$-pinene could explain the differences in the particle size distributions shown in Fig. 13b, as a higher concentration of gas-phase organic acid may result in a more effective scavenging of sCI, thus reducing the formation of new particles in the low-RH chamber compared to the high-RH chamber.

From Fig. 14 it is clear that the composition of the SOA changes significantly following the second injection of $\alpha$-pinene, with increasing relative concentrations of pinic acid, pinonic acid and hydroxy-pinonic acid. In contrast, the concentration of both MBTCA and DTAA is significantly lower in the SOA collected after the second injection of $\alpha$-pinene (about 1.5 and $1 \%$ of total SOA mass, respectively). Absence of $\mathrm{OH}$ in the chamber during night-time is the most likely explanation for this observation. In addition, increased SOA formation from $\mathrm{O}_{3}$-initiated oxidation of $\alpha$-pinene and increased condensation of semi-volatile compounds due to lower night-time temperatures contribute to reducing the normalized MBTCA and DTAA concentrations. Increased condensation at lower night-time temperatures may also explain the significantly larger fraction of semi-volatile compounds, such as pinonic acid, pinic acid and hydroxy-pinonic acid in SOA collected following the second $\alpha$-pinene injection. As indicated above, increased condensation of pinonic acid at lower temperatures also contributes to the observed decrease in MBTCA. 
A

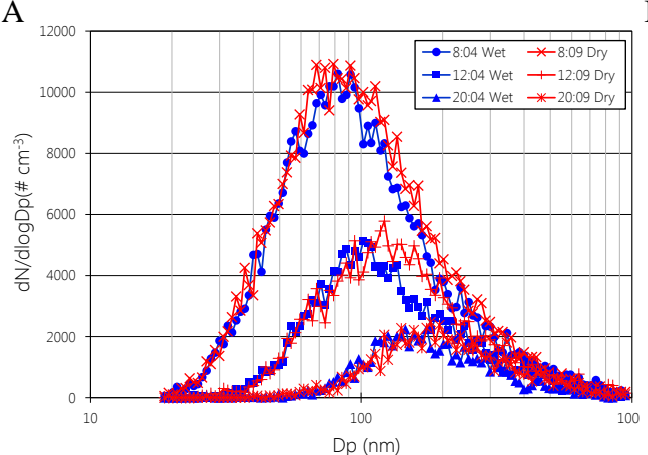

B

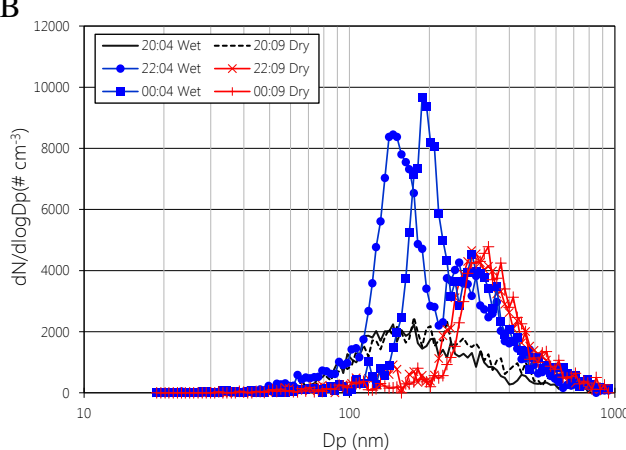

Fig. 13. Particle size distributions in high- (32-90\%, blue) and low- (11-52\%, red) RH chamber during the OH- and ozone-initiated oxidation experiments (experiment 10, Table 1). (A) Particle size distributions following the first injection of $\alpha$-pinene (OH oxidation). (B) Particle size distributions following the second injection of $\alpha$-pinene (ozonolysis). Particle size distributions in the two chambers prior to the second injection are shown in black. Repetition of the experiment (experiments 11-13, Table 1) showed similar particle size distribution as shown in (A) and (B).

The low MBTCA and DTAA concentrations observed following the second injection of $\alpha$-pinene indicates that no significant gas-phase oxidation of already present oxygenated volatile organic compounds (OVOCs) from the preceding $\mathrm{OH}$-initiated oxidation experiment is occurring. Formation of $\mathrm{OH}$ from the ozonolysis of $\alpha$-pinene following the second injection could allow for increased oxidation of OVOC in the chamber, and thus for increased condensation and SOA mass. However, since no increase in MBTCA and DTAA is observed in SOA collected after the second injection, further oxidation by $\mathrm{OH}$ does not seem to be the reason for the increased SOA formation observed during ozonolysis.

In contrast to $\mathrm{SOA}$ produced during $\mathrm{OH}$-oxidation, dimers were identified in SOA generated during ozonolysis following the second injection of $\alpha$-pinene. The composition of the SOA collected after the second injection of $\alpha$-pinene shows a clear RH dependence, with highest relative concentrations of all four dimers in SOA formed at high RH. The presence of dimers in SOA collected after the second injection indicates that the dimers are formed only during ozonolysis of $\alpha$-pinene in accordance with results from individual $\mathrm{OH}$ - and $\mathrm{O}_{3}$-initiated oxidation experiments shown in Fig. 8.

To summarize, $\mathrm{O}_{3}$-initiated oxidation of $\alpha$-pinene is shown to produce a higher SOA mass compared to $\mathrm{OH}-$ initiated oxidation. Furthermore, the reaction of $\alpha$-pinene with $\mathrm{O}_{3}$ results in a more complex SOA due to the formation of dimers in addition to acids. The formation of the dimers is enhanced at higher $\mathrm{RH}$, indicating a possible $\mathrm{RH}$ effect on the chemical composition of SOA from $\alpha$-pinene ozonolysis. Increased new particle formation (Fig. 13b) correlates with increased formation of dimer (Fig. 14), suggesting that the gas-phase formation of the polar, high-molecular weight compounds results in new particle formation by homogenous nucleation.

\section{Atmospheric relevance}

Formation of the dimers identified in this study is currently hypothesized to result from aerosol-phase esterification of carboxylic acids. In this study, the formation of dimers has been shown to occur only during ozonolysis of $\alpha$-pinene and not through $\mathrm{OH}$-oxidation, suggesting that these dimers originate via the gas-phase reaction of a stabilized CI formed by ozonolysis of $\alpha$-pinene. This mechanism is supported by the increase in the formation of dimers observed at higher $\mathrm{RH}$, explained by increased stabilization of the CI, and by previous work, by Witkowski and Gierczak (2013), showing that sCI may react with aldehydes to form higher molecular weight dimers. By contrast, particle-phase esterification of carboxylic acids would be expected to increase at lower RH. Furthermore, recent findings have shown that particlephase Fischer esterification is kinetically unfavourable under atmospheric conditions (Birdsall et al., 2013; DePalma et al., 2013). Yasmeen et al. (2010) observed several dimers during warm summer nights in K-Puszta, Hungary, and suggested that higher temperatures $\left(>24^{\circ} \mathrm{C}\right)$ and high concentrations of pinic acid during night-time could facilitate the formation of dimers. In this study, dimers from $\alpha$-pinene are observed in ozonolysis experiments performed at temperatures as low as $10^{\circ} \mathrm{C}$, proving that dimers may form at low temperatures. Since increased pinic acid concentration, relative to OH-oxidation ( $\sim 1 \%$ of SOA mass), is observed in all $\mathrm{O}_{3}$-initiated oxidation experiments ( $\sim 3 \%$ of SOA mass), it is not possible to rule out formation of the dimers from pinic acid in the particle phase. However, the observation that no trace of dimers is observed in the $\mathrm{OH}$-initiated oxidations, despite the presence of pinic acid and other dimer precursors, indicates that pinic acid does not seem to be the controlling factor in formation of the dimers, and furthermore rules out formation through previously suggested esterification. This conclusion is confirmed in a study showing a low correlation 


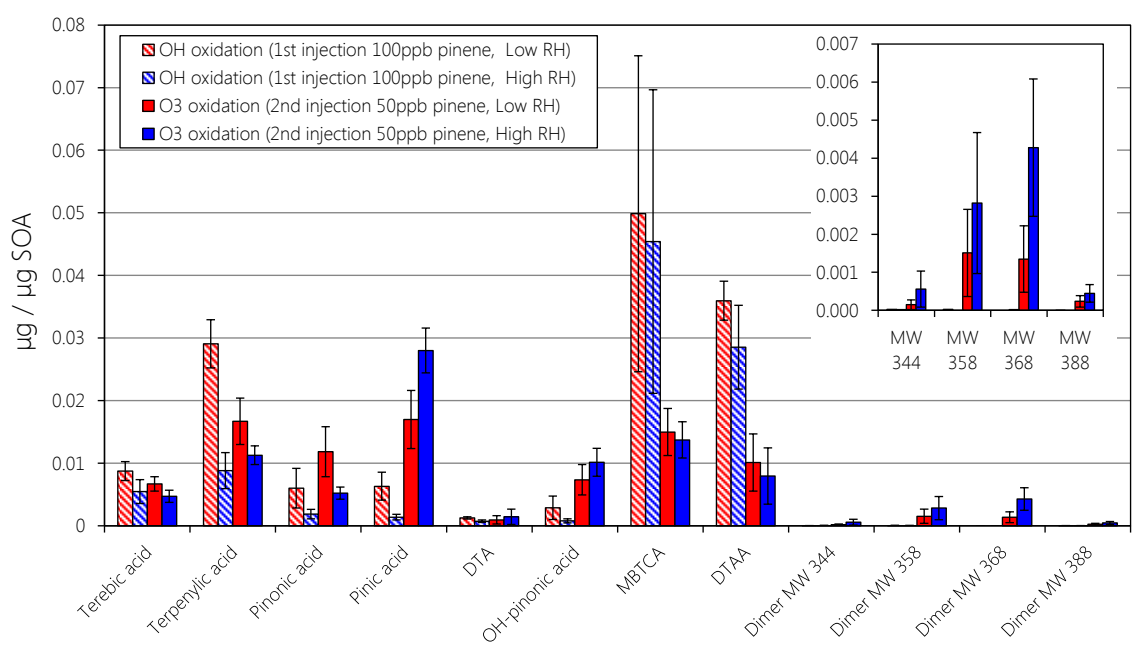

Fig. 14. Normalized concentrations ( $\mu \mathrm{g} \mu \mathrm{g}^{-1} \mathrm{SOA}$ ) of oxidation products from the first and second injection of $\alpha$-pinene at low (red) and high (blue) RH. A total of four experiments were conducted (experiments 10-13, Table 1). Standard deviations $(n=4)$ are indicated by error bars.

between pinic acid and the pinyl-diaterpyl dimer in ambient measurements (Kristensen et al., 2013).

The suggested formation of dimers through an sCI originating from ozonolysis of $\alpha$-pinene would explain the observed diurnal variations of the dimers at both KPuszta, Hungary, and Blodgett Forest, USA (Yasmeen et al., 2010; Kristensen al., 2013). Since OH-initiated oxidation of $\alpha$-pinene dominates during daytime, because of the high concentration of $\mathrm{OH}$ radicals and the fast reaction rate of $\mathrm{OH}$ with $\alpha$-pinene (Atkinson et al., 2006), no dimers are formed. However, during night-time, when the concentration of $\mathrm{OH}$ radicals is low and $\alpha$-pinene is still emitted from the terrestrial system, $\mathrm{O}_{3}$-initiated oxidation of $\alpha$-pinene predominates, leading to the formation of the dimers.

Gas-phase formation could also explain the increased concentration of dimers observed at the higher ambient temperatures of K-Puszta, Hungary, and Blodgett Forest, USA, which would increase gas-phase concentrations of semivolatile pinic and hydroxy-pinonic acids, and thus enhance gas-phase reactions forming high-MW compounds, such as the dimers observed in this study. Higher ambient temperatures might further enhance the gas-phase formation of dimers by increasing the reaction rate of the sCI.

Due to the high molecular weight and polar nature of the dimers, gas-phase formation could result in the homogenous nucleation observed in Fig. 13b. Based on the findings of this study, RH may influence the chemical composition of SOA from both $\mathrm{OH}$-initiated oxidation and ozonolysis of $\alpha$-pinene. The observed effect of increased RH on the formation of $\alpha$-pinene oxidation products indicates that changes in climate may alter the chemical composition of SOA by facilitating the formation of higher MW compounds, such as the dimers. As this study indicates that dimers are formed only through ozonolysis of $\alpha$-pinene, they may be useful trac- ers for $\mathrm{O}_{3}$-initiated oxidation chemistry, and could therefore serve as indicators of increased anthropogenic influence on SOA formation.

\section{Conclusions}

Dimers from $\alpha$-pinene appear to be formed through ozonolysis and not through $\mathrm{OH}$-initiated oxidation, making them potentially useful tracers for atmospheric ozone chemistry and anthropogenic pollution. Despite the presence of the dimer precursors, no dimers were observed in SOA from $\mathrm{OH}$-oxidation of $\alpha$-pinene. This observation along with the increased particle fraction of dimers at higher RH and no significant influence of particle acidity, indicates that the dimers are not formed through the currently postulated particlephase esterification of carboxylic acids. This conclusion is supported by kinetic studies (Heaton et al., 2007) and computational chemistry (DePalma et al., 2013). We suggest that the formation of the dimers through gas-phase reactions of the stabilized CI, can explain the ozone dependence and the fast formation of dimers observed in previous studies. Furthermore, gas-phase formation of the dimers may result in homogenous nucleation, explaining the increased new particle formation during $\alpha$-pinene ozonolysis at higher $\mathrm{RH}$.

Similar concentrations of dimers in low- and high-SOAmass experiments show that the dimers observed in this and previous smog chamber studies are not formed as a consequence of high SOA mass loading. Significantly less particle formation was observed from ozonolysis of $\alpha$-pinene in the presence of AS seed particles coated with products of $\mathrm{OH}+\alpha$-pinene oxidation than in the presence of pure AS seed. This effect is attributed to an increased condensation of newly formed oxidation products from the ozonolysis 
of $\alpha$-pinene onto the less viscous SOA-coated AS seed that depletes the gas-phase concentrations of oxidation products and thus prevents new particle formation through nucleation. This conclusion underlines the influence of seed particles in smog chamber studies, and emphasizes the effect of both composition and physical state of the seed aerosols on new particle formation. Further research is warranted to understand the gas-phase formation of the dimers, which may offer insight into the reactivity and role of Criegee intermediates in the formation of SOA from $\alpha$-pinene.

\section{Supplementary material related to this article is available online at http://www.atmos-chem-phys.net/14/ 4201/2014/acp-14-4201-2014-supplement.pdf.}

Acknowledgements. We acknowledge the VILLUM FOUNDATION and the Aarhus University Research Foundation for funding. We thank Y.-H. Lin, S. Hapsari Budisulistiorini, M. Arashrio, Z. Zhang and K. G. Sexton for help with smog chamber experiments and discussion of the results. This publication was made possible (in part) by EPA grant No. 83540401. Its contents are solely the responsibility of the grantee and do not necessarily represent the official views of the EPA. Further, the EPA does not endorse the purchase of any commercial products or services mentioned in the publication.

Edited by: F. Keutsch

\section{References}

Arey, J., Aschmann, S. M., Kwok, E. S. C., and Atkinson, R.: Alkyl nitrate, hydroxyalkyl nitrate, and hydroxycarbonyl formation from the $\mathrm{NO}_{\mathrm{x}}$-air photooxidations of C-5-C-8 n-alkanes, J. Phys. Chem. A, 105, 1020-1027, doi:10.1021/Jp003292z, 2001.

Atkinson, R. and Arey, J.: Atmospheric chemistry of biogenic organic compounds, Accounts Chem. Res., 31, 574-583, doi:10.1021/Ar970143z, 1998.

Atkinson, R., Baulch, D. L., Cox, R. A., Crowley, J. N., Hampson, R. F., Hynes, R. G., Jenkin, M. E., Rossi, M. J., Troe, J., and IUPAC Subcommittee: Evaluated kinetic and photochemical data for atmospheric chemistry: Volume II - gas phase reactions of organic species, Atmos. Chem. Phys., 6, 3625-4055, doi:10.5194/acp-6-3625-2006, 2006.

Birdsall, A. W., Zentner, C. A., and Elrod, M. J.: Study of the kinetics and equilibria of the oligomerization reactions of 2-methylglyceric acid, Atmos. Chem. Phys., 13, 3097-3109, doi:10.5194/acp-13-3097-2013, 2013.

Bonn, B., Schuster, G., and Moortgat, G. K.: Influence of water vapor on the process of new particle formation during monoterpene ozonolysis, J. Phys. Chem. A, 106, 2869-2881, doi:10.1021/Jp012713p, 2002.

Camredon, M., Hamilton, J. F., Alam, M. S., Wyche, K. P., Carr, T., White, I. R., Monks, P. S., Rickard, A. R., and Bloss, W. J.: Distribution of gaseous and particulate organic composition during dark $\alpha$-pinene ozonolysis, Atmos. Chem. Phys., 10, 2893-2917, doi:10.5194/acp-10-2893-2010, 2010.

Claeys, M., Iinuma, Y., Szmigielski, R., Surratt, J. D., Blockhuys, F., Van Alsenoy, C., Boge, O., Sierau, B., Gomez-Gonzalez, Y., Vermeylen, R., Van der Veken, P., Shahgholi, M., Chan, A. W. H., Herrmann, H., Seinfeld, J. H., and Maenhaut, W.: Terpenylic Acid and Related Compounds from the Oxidation of alpha-Pinene: Implications for New Particle Formation and Growth above Forests, Environ. Sci. Technol., 43, 6976-6982, doi:10.1021/Es9007596, 2009.

Cruz, C. N. and Pandis, S. N.: Deliquescence and hygroscopic growth of mixed inorganic-organic atmospheric aerosol, Environ. Sci. Technol., 34, 4313-4319, doi:10.1021/Es9907109, 2000.

DePalma, J. W., Horan, A. J., Hall, W. A., and Johnston, M. V.: Thermodynamics of oligomer formation: implications for secondary organic aerosol formation and reactivity, Phys. Chem. Chem. Phys., 15, 6935-6944, doi:10.1039/c3cp44586k, 2013.

Docherty, K. S., Wu, W., Lim, Y. B., and Ziemann, P. J.: Contributions of organic peroxides to secondary aerosol formed from reactions of monoterpenes with O-3, Environ. Sci. Technol., 39, 4049-4059, doi:10.1021/Es050228s, 2005.

Donahue, N. M., Robinson, A. L., Stanier, C. O., and Pandis, S. N.: Coupled partitioning, dilution, and chemical aging of semivolatile organics, Environ. Sci. Technol., 40, 2635-2643, doi:10.1021/Es052297c, 2006.

Fry, J. L., Kiendler-Scharr, A., Rollins, A. W., Wooldridge, P. J., Brown, S. S., Fuchs, H., Dubé, W., Mensah, A., dal Maso, M., Tillmann, R., Dorn, H.-P., Brauers, T., and Cohen, R. C.: Organic nitrate and secondary organic aerosol yield from $\mathrm{NO}_{3}$ oxidation of $\beta$-pinene evaluated using a gas-phase kinetics/aerosol partitioning model, Atmos. Chem. Phys., 9, 14311449, doi:10.5194/acp-9-1431-2009, 2009.

Gao, S., Ng, N. L., Keywood, M., Varutbangkul, V., Bahreini, R., Nenes, A., He, J. W., Yoo, K. Y., Beauchamp, J. L., Hodyss, R. P., Flagan, R. C., and Seinfeld, J. H.: Particle phase acidity and oligomer formation in secondary organic aerosol, Environ. Sci. Technol., 38, 6582-6589, doi:10.1021/Es049125k, 2004.

Gao, Y. Q., Hall, W. A., and Johnston, M. V.: Molecular composition of monoterpene secondary organic aerosol at low mass loading, Environ. Sci. Technol., 44, 7897-7902, doi:10.1021/Es101861k, 2010.

Glasius, M., Lahaniati, M., Calogirou, A., Di Bella, D., Jensen, N. R., Hjorth, J., Kotzias, D., and Larsen, B. R.: Carboxylic acids in secondary aerosols from oxidation of cyclic monoterpenes by ozone, Environ. Sci. Technol., 34, 1001-1010, doi:10.1021/Es990445r, 2000.

Guenther, A., Hewitt, C. N., Erickson, D., Fall, R., Geron, C., Graedel, T., Harley, P., Klinger, L., Lerdau, M., Mckay, W. A., Pierce, T., Scholes, B., Steinbrecher, R., Tallamraju, R., Taylor, J., and Zimmerman, P.: A Global-Model of Natural Volatile Organic-Compound Emissions, J. Geophys. Res.-Atmos., 100, 8873-8892, doi:10.1029/94jd02950, 1995.

Hallquist, M., Wenger, J. C., Baltensperger, U., Rudich, Y., Simpson, D., Claeys, M., Dommen, J., Donahue, N. M., George, C., Goldstein, A. H., Hamilton, J. F., Herrmann, H., Hoffmann, T., Iinuma, Y., Jang, M., Jenkin, M. E., Jimenez, J. L., Kiendler-Scharr, A., Maenhaut, W., McFiggans, G., Mentel, Th. F., Monod, A., Prévôt, A. S. H., Seinfeld, J. H., Surratt, J. D., 
Szmigielski, R., and Wildt, J.: The formation, properties and impact of secondary organic aerosol: current and emerging issues, Atmos. Chem. Phys., 9, 5155-5236, doi:10.5194/acp-9-51552009, 2009.

Heaton, K. J., Dreyfus, M. A., Wang, S., and Johnston, M. V.: Oligomers in the early stage of biogenic secondary organic aerosol formation and growth, Environ. Sci. Technol., 41, 61296136, doi:10.1021/Es070314n, 2007.

Hoffmann, T., Odum, J. R., Bowman, F., Collins, D., Klockow, D., Flagan, R. C., and Seinfeld, J. H.: Formation of organic aerosols from the oxidation of biogenic hydrocarbons, J. Atmos. Chem., 26, 189-222, doi:10.1023/A:1005734301837, 1997.

Hoffmann, T., Bandur, R., Marggraf, U., and Linscheid, M.: Molecular composition of organic aerosols formed in the alpha-pinene/O-3 reaction: Implications for new particle formation processes, J. Geophys. Res.-Atmos., 103, 25569-25578, doi:10.1029/98jd01816, 1998.

Iinuma, Y., Müller, C., Berndt, T., Boge, O., Claeys, M., and Herrmann, H.: Evidence for the existence of organosulfates from beta-pinene ozonolysis in ambient secondary organic aerosol, Environ. Sci. Technol., 41, 6678-6683, doi:10.1021/Es070938t, 2007.

Iinuma, Y., Kahnt, A., Mutzel, A., Böge, O., and Herrmann, H.: Ozone-Driven Secondary Organic Aerosol Production Chain, Environ. Sci. Technol., 47, 3639-3647, doi:10.1021/Es305156z, 2013.

Jenkin, M. E., Shallcross, D. E., and Harvey, J. N.: Development and application of a possible mechanism for the generation of cispinic acid from the ozonolysis of alpha- and beta-pinene, Atmos. Environ., 34, 2837-2850, 2000.

Jimenez, J. L., Canagaratna, M. R., Donahue, N. M., Prevot, A. S. H., Zhang, Q., Kroll, J. H., DeCarlo, P. F., Allan, J. D., Coe, H., Ng, N. L., Aiken, A. C., Docherty, K. S., Ulbrich, I. M., Grieshop, A. P., Robinson, A. L., Duplissy, J., Smith, J. D., Wilson, K. R., Lanz, V. A., Hueglin, C., Sun, Y. L., Tian, J., Laaksonen, A., Raatikainen, T., Rautiainen, J., Vaattovaara, P., Ehn, M., Kulmala, M., Tomlinson, J. M., Collins, D. R., Cubison, M. J., Dunlea, E. J., Huffman, J. A., Onasch, T. B., Alfarra, M. R., Williams, P. I., Bower, K., Kondo, Y., Schneider, J., Drewnick, F., Borrmann, S., Weimer, S., Demerjian, K., Salcedo, D., Cottrell, L., Griffin, R., Takami, A., Miyoshi, T., Hatakeyama, S., Shimono, A., Sun, J. Y., Zhang, Y. M., Dzepina, K., Kimmel, J. R., Sueper, D., Jayne, J. T., Herndon, S. C., Trimborn, A. M., Williams, L. R., Wood, E. C., Middlebrook, A. M., Kolb, C. E., Baltensperger, U., and Worsnop, D. R.: Evolution of Organic Aerosols in the Atmosphere, Science, 326, 1525-1529, doi:10.1126/science.1180353, 2009.

Jonsson, A. M., Hallquist, M., and Ljungstrom, E.: Impact of humidity on the ozone initiated oxidation of limonene, Delta(3)carene, and alpha-pinene, Environ. Sci. Technol., 40, 188-194, doi:10.1021/Es051163w, 2006.

Kahnt, A., Iinuma, Y., Mutzel, A., Böge, O., Claeys, M., and Herrmann, H.: Campholenic aldehyde ozonolysis: a mechanism leading to specific biogenic secondary organic aerosol constituents, Atmos. Chem. Phys., 14, 719-736, doi:10.5194/acp14-719-2014, 2014.

Kalberer, M., Paulsen, D., Sax, M., Steinbacher, M., Dommen, J., Prevot, A. S. H., Fisseha, R., Weingartner, E., Frankevich, V., Zenobi, R., and Baltensperger, U.: Identification of polymers as major components of atmospheric organic aerosols, Science, 303, 1659-1662, doi:10.1126/science.1092185, 2004.

Kamens, R. M., Zhang, H. F., Chen, E. H., Zhou, Y., Parikh, H. M., Wilson, R. L., Galloway, K. E., and Rosen, E. P.: Secondary organic aerosol formation from toluene in an atmospheric hydrocarbon mixture: Water and particle seed effects, Atmos. Environ., 45, 2324-2334, doi:10.1016/j.atmosenv.2010.11.007, 2011.

Kristensen, K., Enggrob, K. L., King, S. M., Worton, D. R., Platt, S. M., Mortensen, R., Rosenoern, T., Surratt, J. D., Bilde, M., Goldstein, A. H., and Glasius, M.: Formation and occurrence of dimer esters of pinene oxidation products in atmospheric aerosols, Atmos. Chem. Phys., 13, 3763-3776, doi:10.5194/acp-13-37632013, 2013.

Kroll, J. H. and Seinfeld, J. H.: Chemistry of secondary organic aerosol: Formation and evolution of low-volatility organics in the atmosphere, Atmos. Environ., 42, 3593-3624, doi:10.1016/j.atmosenv.2008.01.003, 2008.

Larsen, B. R., Di Bella, D., Glasius, M., Winterhalter, R., Jensen, N. R., and Hjorth, J.: Gas-phase $\mathrm{OH}$ oxidation of monoterpenes: Gaseous and particulate products, J. Atmos. Chem., 38, 231-276, doi:10.1023/A:1006487530903, 2001.

Lee, S. D., Jang, M. S., and Kamens, R. M.: SOA formation from the photooxidation of alpha-pinene in the presence of freshly emitted diesel soot exhaust, Atmos. Environ., 38, 2597-2605, doi:10.1016/j.atmosenv.2003.12.041, 2004.

Leungsakul, S., Jeffries, H. E., and Kamens, R. M.: A kinetic mechanism for predicting secondary aerosol formation from the reactions of d-limonene in the presence of oxides of nitrogen and natural sunlight, Atmos. Environ., 39, 7063-7082, doi:10.1016/j.atmosenv.2005.08.024, 2005.

Müller, L., Reinnig, M.-C., Warnke, J., and Hoffmann, Th.: Unambiguous identification of esters as oligomers in secondary organic aerosol formed from cyclohexene and cyclohexene $/ \alpha$ pinene ozonolysis, Atmos. Chem. Phys., 8, 1423-1433, doi:10.5194/acp-8-1423-2008, 2008.

Müller, L., Reinnig, M. C., Hayen, H., and Hoffmann, T.: Characterization of oligomeric compounds in secondary organic aerosol using liquid chromatography coupled to electrospray ionization Fourier transform ion cyclotron resonance mass spectrometry, Rapid Commun. Mass Sp., 23, 971-979, doi:10.1002/Rcm.3957, 2009.

Müller, L., Reinnig, M.-C., Naumann, K. H., Saathoff, H., Mentel, T. F., Donahue, N. M., and Hoffmann, T.: Formation of 3-methyl1,2,3-butanetricarboxylic acid via gas phase oxidation of pinonic acid - a mass spectrometric study of SOA aging, Atmos. Chem. Phys., 12, 1483-1496, doi:10.5194/acp-12-1483-2012, 2012.

Odum, J. R., Hoffmann, T., Bowman, F., Collins, D., Flagan, R. C., and Seinfeld, J. H.: Gas/particle partitioning and secondary organic aerosol yields, Environ. Sci. Technol., 30, 2580-2585, doi:10.1021/Es950943+, 1996.

Perraud, V., Bruns, E. A., Ezell, M. J., Johnson, S. N., Greaves, J., and Finlayson-Pitts, B. J.: Identification of Organic Nitrates in the $\mathrm{NO}_{3}$ Radical Initiated Oxidation of alpha-Pinene by Atmospheric Pressure Chemical Ionization Mass Spectrometry, Environ. Sci. Technol., 44, 5887-5893, doi:10.1021/Es1005658, 2010.

Prenni, A. J., DeMott, P. J., Kreidenweis, S. M., Sherman, D. E., Russell, L. M., and Ming, Y.: The effects of low molecular weight 
dicarboxylic acids on cloud formation, J. Phys. Chem. A, 105, 11240-11248, doi:10.1021/Jp012427d, 2001.

Renbaum-Wolff, L., Grayson, J. W., Bateman, A. P., Kuwata, M., Sellier, M., Murray, B. J., Shilling, J. E., Martin, S. T., and Bertram, A. K.: Viscosity of alpha-pinene secondary organic material and implications for particle growth and reactivity, P. Natl. Acad. Sci. USA, 110, 8014-8019, doi:10.1073/pnas.1219548110, 2013.

Saathoff, H., Naumann, K.-H., Möhler, O., Jonsson, A. M., Hallquist, M., Kiendler-Scharr, A., Mentel, Th. F., Tillmann, R., and Schurath, U.: Temperature dependence of yields of secondary organic aerosols from the ozonolysis of $\alpha$-pinene and limonene, Atmos. Chem. Phys., 9, 1551-1577, doi:10.5194/acp9-1551-2009, 2009.

Surratt, J. D., Gomez-Gonzalez, Y., Chan, A. W. H., Vermeylen, R., Shahgholi, M., Kleindienst, T. E., Edney, E. O., Offenberg, J. H., Lewandowski, M., Jaoui, M., Maenhaut, W., Claeys, M., Flagan, R. C., and Seinfeld, J. H.: Organosulfate formation in biogenic secondary organic aerosol, J. Phys. Chem. A, 112, 8345-8378, doi:10.1021/Jp802310p, 2008.

Szmigielski, R., Surratt, J. D., Gomez-Gonzalez, Y., Van der Veken, P., Kourtchev, I., Vermeylen, R., Blockhuys, F., Jaoui, M., Kleindienst, T. E., Lewandowski, M., Offenberg, J. H., Edney, E. O., Seinfeld, J. H., Maenhaut, W., and Claeys, M.: 3-methyl1,2,3-butanetricarboxylic acid: An atmospheric tracer for terpene secondary organic aerosol, Geophys. Res. Lett., 34, L24811, doi:10.1029/2007g1031338, 2007.

Tolocka, M. P., Jang, M., Ginter, J. M., Cox, F. J., Kamens, R. M., and Johnston, M. V.: Formation of oligomers in secondary organic aerosol, Environ. Sci. Technol., 38, 1428-1434, doi:10.1021/Es035030r, 2004.

Vereecken, L., Muller, J. F., and Peeters, J.: Low-volatility poly-oxygenates in the $\mathrm{OH}$-initiated atmospheric oxidation of alpha-pinene: impact of non-traditional peroxyl radical chemistry, Phys. Chem. Chem. Phys., 9, 5241-5248, doi:10.1039/B708023a, 2007.

Warneke, C., de Gouw, J. A., Goldan, P. D., Kuster, W. C., Williams, E. J., Lerner, B. M., Jakoubek, R., Brown, S. S., Stark, H., Aldener, M., Ravishankara, A. R., Roberts, J. M., Marchewka, M., Bertman, S., Sueper, D. T., McKeen, S. A., Meagher, J. F., and Fehsenfeld, F. C.: Comparison of daytime and nighttime oxidation of biogenic and anthropogenic VOCs along the New England coast in summer during New England Air Quality Study 2002, J. Geophys. Res.-Atmos., 109, D10309, doi:10.1029/2003jd004424, 2004.
Witkowski, B. and Gierczak, T.: Analysis of alphaacyloxyhydroperoxy aldehydes with electrospray ionizationtandem mass spectrometry (ESI-MSn), J. Mass Spectrom., 48, 79-88, doi:10.1002/jms.3130, 2013.

Yasmeen, F., Vermeylen, R., Szmigielski, R., Inuma, Y., Böge, O., Herrmann, H., Maenhaut, W., and Claeys, M.: Terpenylic acid and related compounds: precursors for dimers in secondary organic aerosol from the ozonolysis of $\alpha$ - and $\beta$-pinene, Atmos. Chem. Phys., 10, 9383-9392, doi:10.5194/acp-10-9383-2010, 2010.

Yu, J. Z., Cocker, D. R., Griffin, R. J., Flagan, R. C., and Seinfeld, J. H.: Gas-phase ozone oxidation of monoterpenes: Gaseous and particulate products, J. Atmos. Chem., 34, 207-258, doi:10.1023/A:1006254930583, 1999.

Zhang, H., Surratt, J. D., Lin, Y. H., Bapat, J., and Kamens, R. M.: Effect of relative humidity on SOA formation from isoprene/NO photooxidation: enhancement of 2-methylglyceric acid and its corresponding oligoesters under dry conditions, Atmos. Chem. Phys., 11, 6411-6424, doi:10.5194/acp-11-6411-2011, 2011.

Zhang, H. F., Lin, Y. H., Zhang, Z. F., Zhang, X. L., Shaw, S. L., Knipping, E. M., Weber, R. J., Gold, A., Kamens, R. M., and Surratt, J. D.: Secondary organic aerosol formation from methacrolein photooxidation: roles of NOx level, relative humidity and aerosol acidity, Environ. Chem., 9, 247-262, doi:10.1071/En12004, 2012.

Zhang, Y. Y., Müller, L., Winterhalter, R., Moortgat, G. K., Hoffmann, T., and Pöschl, U.: Seasonal cycle and temperature dependence of pinene oxidation products, dicarboxylic acids and nitrophenols in fine and coarse air particulate matter, Atmos. Chem. Phys., 10, 7859-7873, doi:10.5194/acp-10-7859-2010, 2010. 